(c) American Dairy Science Association, 2003.

\title{
Effects of Forage Particle Size, Forage Source, and Grain Fermentability on Performance and Ruminal pH in Midlactation Cows
}

\author{
K. M. Krause and D. K. Combs \\ Department of Dairy Science, \\ University of Wisconsin-Madison 53706
}

\begin{abstract}
Our study investigated the effects of, and interactions between, forage particle size, level of dietary ruminally fermentable carbohydrate (RFC), and level of dietary starch on performance, chewing activity, and ruminal $\mathrm{pH}$ for dairy cows fed one level of dietary NDF. Twelve cows (48 DIM) were assigned to six treatments in a replicated $6 \times 6$ Latin square. Treatments were arranged in an incomplete $2 \times 2 \times 2$ factorial design. Factors were: dry cracked shelled corn (DC, low RFC) or ground high-moisture corn (HMC; high RFC), finely chopped or coarse silage, and alfalfa silage as the only forage or a 50:50 ratio (DM basis) of alfalfa and corn silage. Diets combining HMC with only alfalfa silage were not included in the experiment. Diets were fed for ad libitum intake as a TMR with a concentrate:forage ratio of 61:39. Diets based on only alfalfa silage and diets based on a mix of alfalfa and corn silage averaged 18.6 and $15.8 \% \mathrm{CP}, 25.8$ and $24.7 \% \mathrm{NDF}, 17.7$ and $14.8 \% \mathrm{ADF}$, and 29.1 and $37.3 \%$ starch, respectively. Mean particle sizes were $5.3,2.7,5.6$, and $2.8 \mathrm{~mm}$ for coarse alfalfa, fine alfalfa, coarse corn silage, and fine corn silage, respectively. Decreasing forage particle size decreased DMI (23.3 vs. $21.6 \mathrm{~kg}$ ) and organic matter intake (22.0 vs. $20.2 \mathrm{~kg})$. Increasing RFC decreased DMI (22.8 vs. $21.0 \mathrm{~kg})$ and organic matter intake (21.5 vs. $20.0 \mathrm{~kg}$ ). Decreasing forage particle size increased energy-corrected milk for alfalfa based diets (34.9 vs. $37.4 \mathrm{~kg}$ ). Percentage of milk fat decreased with decreasing forage particle size (3.07 vs. $2.90 \%)$ and increased level of RFC (3.04 vs. 2.57\%). Percentage of protein increased when corn silage partially replaced alfalfa silage (2.84 vs. $2.90 \%)$ but decreased when HMC replaced DC (2.90 vs. $2.84 \%)$. Apparent total tract digestibility of DM (66.7 vs. $68.5 \%)$, OM (65.9 vs. $70.7 \%)$, and starch (88.9 vs. 93.4\%) increased when level of RFC was increased. Increasing level of RFC decreased mean ruminal $\mathrm{pH}$ from 5.82 to 5.67 and decreased minimum
\end{abstract}

Received August 19, 2002

Accepted November 11, 2002.

Corresponding author: D. K. Combs; e-mail: dkcombs@facstaff. wisc.edu.
$\mathrm{pH}$. Hours per day at which $\mathrm{pH}$ was $<5.8$, and area $<5.8$, increased when corn silage partially replaced alfalfa silage ( 2.6 vs. $4.4 \mathrm{~h}$ and $8.9 \mathrm{~h} \times \mathrm{pH}$ vs. $11.4 \mathrm{~h} \times \mathrm{pH})$ and decreased further when level of RFC was increased (4.4 vs. $6.4 \mathrm{~h}$ and $11.4 \mathrm{~h} \times \mathrm{pH}$ vs. $14.3 \mathrm{~h} \times \mathrm{pH})$. Decreasing forage particle size in HMC diets increased hours and area $<5.8$, but for DC diets, the effect of forage particle size depended on forage source. Interactions were found between level of physically effective fiber, forage source, and level of RFC on production and $\mathrm{pH}$, complicating the inclusion of these effects in dairy ration formulation and evaluation.

(Key words: fermentable carbohydrate, forage particle size, production, rumen fermentation)

Abbreviation key: $\mathbf{A}=$ alfalfa silage, $\mathbf{A C}=$ alfalfa silage and corn silage, $\mathbf{C}=$ coarse silage, $\mathbf{D C}=$ dry corn, DCCA = dry cracked shelled corn and coarse alfalfa silage, DCCAC = dry cracked shelled corn and coarse alfalfa/corn silage, DCFA = dry cracked shelled corn and fine alfalfa silage, DCFAC = dry cracked shelled corn and fine alfalfa/corn silage, DOMI = digestible organic matter, $\mathbf{E C M}=$ energy-corrected milk, $\mathbf{F}=$ finely chopped silage, HMC = high-moisture corn, HMCCAC = ground HMC and coarse alfalfa/corn silage, HMCFAC = ground HMC and fine alfalfa/corn silage, $\mathbf{O M I}=$ organic matter intake, $\mathbf{p e N D F}=$ physically effective NDF, RFC = ruminally fermentable carbohydrate.

\section{INTRODUCTION}

Maximizing the energy intake of the dairy cow is an important goal in nutrition as the genetic potential for dairy cows to produce milk increases. This is especially important for cows in early lactation, when energy expenditure often exceeds the energy consumed. The addition of highly digestible carbohydrate to the diet is a common method of increasing the energy available to the cow. Ruminally fermented carbohydrate can also increase microbial protein yield (Nocek and Tamminga, 1991; Krause et al., 2002a), but high amounts of fermentable carbohydrate increase the risk of ruminal acidosis. 
The level of carbohydrates in the diet and the fermentability of these carbohydrates greatly affect the amount of fermentation acids produced in the rumen. Fermentation acid production in the rumen needs to be balanced with their removal and neutralization (Allen, 1997). The buffering capacity of the diet is determined largely by total chewing time because cows secrete more salivary buffer during chewing than during resting (Bailey and Balch, 1961). Physically effective NDF (peNDF) has been defined as the fraction of feed that stimulates chewing (Mertens, 1997) and is a reflection of the physical characteristics of the fiber, such as particle length.

The relationship between forage particle size and ruminal $\mathrm{pH}$ has been well documented (Grant et al., 1990a, Grant et al., 1990b; Beauchemin, 1991; Krause et al., 2002b). Few studies have investigated the effect of level of ruminally fermentable carbohydrate on ruminal $\mathrm{pH}$, but Krause et al. (2002b) found that replacing dry cracked corn with high-moisture corn in a TMR fed to dairy cattle reduced mean ruminal $\mathrm{pH}$ significantly. This study also investigated the effect of forage particle size on ruminal $\mathrm{pH}$ using two levels of forage particle size combined with two levels of ruminally fermentable carbohydrate at a similar level of dietary starch and NDF. Performance of midlactation cows was not affected, but the effects of forage particle size and level of ruminally fermentable carbohydrates on ruminal $\mathrm{pH}$ were found to be additive.

The objectives of this study were to investigate the effects of, and interactions between, level of dietary ruminally fermentable carbohydrates, forage particle size and level of dietary starch (forage source) on DMI, performance, digestibility, microbial yield, ruminal $\mathrm{pH}$ and chewing activity in midlactation dairy cows. We hypothesized that the effect of reducing the level of physically effective fiber on performance and ruminal $\mathrm{pH}$ would depend on the level of ruminally fermentable carbohydrate and the level of dietary starch.

\section{MATERIALS AND METHODS}

\section{Cows and Diets}

Twelve multiparous Holstein cows were assigned randomly to one of two squares in a replicated $6 \times 6$ Latin square. Cows were fitted with ruminal cannulas and averaged $48 \pm 15$ DIM (mean \pm SD) at the start of the experiment. Average BW was $632 \pm 73 \mathrm{~kg}$ at the beginning of the experiment and $671 \pm 72 \mathrm{~kg}$ (mean \pm $\mathrm{SD})$ at the end of the experiment. Experimental periods were $18 \mathrm{~d}$ in duration ( $10 \mathrm{~d}$ of treatment adaptation and $8 \mathrm{~d}$ of data collection). Rumen contents were switched between cows at the end of each experimental period in order to facilitate adaptation to the new experimental diet. Treatments were arranged in an incomplete $2 \times$ $2 \times 2$ factorial design; two levels of forage particle size (fine and coarse) were combined with concentrates based on either dry cracked shelled corn (DC; 89.7\% DM) or ground high-moisture shelled corn (HMC; $73.1 \% \mathrm{DM}$ ), and the forage was either only alfalfa silage or a 50:50 mix (DM basis) of alfalfa silage and corn silage. However, the diets combining HMC with pure alfalfa silage were not included in the experiment. By replacing part of the alfalfa silage with corn silage, the level of dietary starch and fermentability of the diet was increased. However, this increase in fermentability of the diet is confounded with change in forage source and the change in NDF characteristics that accompany it; hence, this effect is referred to as a forage effect. Ruminal fermentability of the diet was further increased by replacing DC with HMC. This effect is referred to as the effect of level of ruminally fermentable carbohydrate (RFC). When the effect of RFC is discussed, it is referring to diets based on a mix of alfalfa and corn silage, as diets combining HMC with pure alfalfa silage were not included in the experiment.

The HMC was inoculated with Lactobacillus buchneri at the time of ensiling at a rate of $5 \times 10^{5} \mathrm{cfu} / \mathrm{g}$ of fresh material. Dry cracked shelled corn and ground HMC was used in this trial because of the relative difference in ruminal starch degradability (68 and $86 \%$ for dry cracked shelled corn and HMC, respectively; Nocek and Tamminga, 1991). First-cut wilted alfalfa silage was harvested at the early to midbloom stage and was chopped with a Gehl Implement, model number 865 forage chopper (Gehl Implement, West Bend, WI) with a head model number 1210 adjusted to cut forage at 1.9$\mathrm{cm}$ theoretical length of cut. Corn silage was harvested using a New Holland model 790 forage chopper adjusted to cut forage at a $1.9-\mathrm{cm}$ theoretical length of cut. Forages were ensiled in two $3.7 \times 12.2-\mathrm{m}$ concrete stave silos. These two silages provided the coarse silages for the diets. Finely chopped silage was obtained by recutting the ensiled alfalfa and corn silage through a 1.9$\mathrm{cm}$ screen in a forage recutter (Gehl, West Bend, WI) daily for the duration of the trial. Nutrient compositions of silages and corn grains are given in Table 1. Geometric mean particle sizes of the forages and the corn grains are given in Table 2. Alfalfa silage and corn silage had similar NDF content and mean particle size. Accordingly, the physical effectiveness of these two silages is similar (Kononoff et al., 1999). Replacing alfalfa silage with corn silage, therefore, provided a means by which dietary starch could be increased without changing the concentrate-to-forage ratio and the dietary level of physically effective fiber substantially. The six diets were: dry cracked shelled corn and coarse alfalfa silage (DCCA), dry cracked shelled corn and coarse alfalfa/ 
Table 1. Nutrient content of silages and corn grain.

\begin{tabular}{llrrr}
\hline & \multicolumn{3}{c}{ Feed } \\
\cline { 2 - 5 } & Alfalfa silage $^{1}$ & Corn silage $^{1}$ & Dry cracked corn $^{1}$ & High-moisture $^{\text {corn }^{1}}$ \\
\hline DM, \% & $51.2 \pm 2.9$ & $39.6 \pm 3.0$ & $89.7 \pm 0.9$ & $73.1 \pm 1.2$ \\
CP, \% of DM & $22.1 \pm 0.9$ & $7.7 \pm 1.0$ & $6.9 \pm 0.8$ & $7.1 \pm 1.4$ \\
NDF, \% of DM & $38.6 \pm 2.1$ & $34.2 \pm 2.0$ & $8.8 \pm 0.9$ & $9.0 \pm 0.9$ \\
ADF, \% of DM & $32.7 \pm 1.5$ & $21.0 \pm 2.0$ & $3.0 \pm 0.8$ & $3.3 \pm 1.2$ \\
Starch, \% of DM & $3.2 \pm 1.6$ & $32.7 \pm 2.4$ & $63.9 \pm 2.5$ & $65.5 \pm 2.5$ \\
\hline
\end{tabular}

${ }^{1}$ Mean $\pm \mathrm{SD}$.

corn silage (DCCAC), dry cracked shelled corn and fine alfalfa silage (DCFA), dry cracked shelled corn and fine alfalfa/corn silage (DCFAC), ground HMC and coarse alfalfa/corn silage (HMCCAC), and ground HMC and fine alfalfa/corn silage (HMCFAC). All diets were formulated to meet or exceed the requirements of a 650$\mathrm{kg}$ multiparaous cow producing $45 \mathrm{~kg}$ milk/d containing $3.4 \%$ milk fat, $3.0 \%$ true protein, and $4.8 \%$ lactose, according to NRC (2001). Diet formulations are given in Table 3.

Table 2. Mean geometric particle size of corn grain, forages and TMR.

Mean $(\mathrm{mm})$ $\pm \mathrm{SD}(\mathrm{mm})$

Dry cracked shell corn ${ }^{1}$

High-moisture shelled corn

Coarse alfalfa silage ${ }^{2}$

Fine alfalfa silage

Coarse corn silage

Fine corn silage

DCCA $^{3}$

DCCAC $^{3}$

DCFA $^{3}$

DCFAC $^{3}$

$\mathrm{HMCCAC}^{3}$

HMCFAC $^{3}$

$0.32 \pm 0.08$

$0.39 \pm 0.09$

$5.3 \pm 1.15$

$2.7 \pm 0.13$

$5.6 \pm 0.23$

$2.8 \pm 0.42$

$3.5 \pm 0.42$

$3.6 \pm 0.36$

$2.5 \pm 0.13$

$2.6 \pm 0.25$

$4.2 \pm 0.32$

$2.8 \pm 0.17$

${ }^{1}$ Mean geometric particle size of corn grain was determined by drysieving according to ASAE (1995) standards.

${ }^{2}$ Mean geometric particle sizes of forages and TMR were determined by dry-sieving using the UW forage particle size separator in accordance with ASAE standard S424 (1988). Diagonal diameters of openings in screens were: $26.90,18.00,8.98,5.61$, and $1.65 \mathrm{~mm}$. Distribution of particles, in percentage of total mass, on the five screens and the pan, respectively, were: coarse alfalfa silage: $8.6,9.1,21.8,15.4$, 21.5, 23.6; fine alfalfa silage: $0.0,0.1,11.0,17.1,39.5,32.3$; coarse corn silage: $1.7,4.7,27.5,25.1,32.5,8.6$; fine corn silage: $0.0,0.4$, 10.8, 17.6, 40.2, 31.0; DCCA: $1.8,4.4,14.8,21.2,27.5,30.3$; DCCAC: 1.7, 4.4, 15.9, 22.0, 27.4, 28.6; DCFA: $0.0,0.1,7.9,21.0,33.6,37.4$ DCFAC: $0.0,0.1,9.2,21.8,32.0,37.0$; HMCCAC: $1.6,4.2,25.1,20.9$, 18.2, 27.6; HMCFAC: $0.0,0.0,13.9,23.2,26.2,36.7$.

${ }^{3}$ Treatments: DCCA = dry cracked shelled corn and coarse alfalfa silage, DCCAC = dry cracked shelled corn and coarse alfalfa/corn silage, DCFA = dry cracked shelled corn and fine alfalfa silage, DCFAC = dry cracked shelled corn and fine alfalfa/corn silage, HMCCAC = ground high-moisture shelled corn and coarse alfalfa/ corn silage, HMCFAC = ground high-moisture shelled corn and fine alfalfa/corn silage.
Diets were fed as a TMR with a concentrate-to-forage ratio of 61:39 (DM basis). Cows were fed ad libitum ( $10 \%$ refusals), and feed was offered twice daily at 0730 and $1930 \mathrm{~h}$ with approximately $65 \%$ of the feed allocated at the morning feeding and the rest at the evening feeding. Intake and milk production were recorded daily throughout the experiment. Feed and ort samples were taken on three separate days during the 8-d data collection period, and intake of nutrients was corrected for nutrient content of orts. Dry matter $\left(60^{\circ} \mathrm{C}\right)$ of feed components was determined weekly and diets adjusted to account for changes in DM content. Cows were cared for according to guidelines of The Research Animal and Resource Committee of the University of WisconsinMadison, and all experimental procedures performed on the animals were approved. Cows were housed in stalls bedded with rubber mattresses and wood shavings and were milked twice daily at 0300 and $1500 \mathrm{~h}$ in a milking parlor. Cows were turned outside for 1 to 2 $\mathrm{h}$ daily after being milked, except on days when chewing activity was monitored. Milk was sampled on consecutive p.m. and a.m. milkings on $3 \mathrm{~d}$ during each period, and milk components were determined by AgSource, Menomonie, WI, using a near infrared reflectance spectroscopy analyzer (MilkoScan 605; Foss Electric, Hillerød, Denmark). True milk protein, and not crude protein, was measured. Yield of energy-corrected milk (ECM) was calculated from the energy output in milk using the equation by Tyrrell and Reid $\left(1965 ; \mathrm{NE}_{\mathrm{L}}\right.$, $\mathrm{Mcal} / \mathrm{d}=$ milk yield, $\mathrm{kg} / \mathrm{d} \times[(0.0929 \times$ percentage of fat $)+(0.0563 \times$ percentage of true protein $)+(0.0395 \times$ percentage of lactose)], divided by the assumed energy content of $4 \% \mathrm{FCM}$ of $0.749 \mathrm{NE}_{\mathrm{L}}, \mathrm{Mcal} / \mathrm{kg}$.

\section{Feed Analysis}

Samples of all feeds, diets, and orts were dried at $60^{\circ} \mathrm{C}$ in a forced-air oven and composited by period. Dried samples were ground to pass a 1-mm screen (Wiley Mill, Arthur H. Thomas, Philadelphia, PA). Analytical DM content of feeds was determined by oven-drying at $100^{\circ} \mathrm{C}$ for $12 \mathrm{~h}$; OM was determined by ashing at 
Table 3. Composition and nutrient content of dietary treatments.

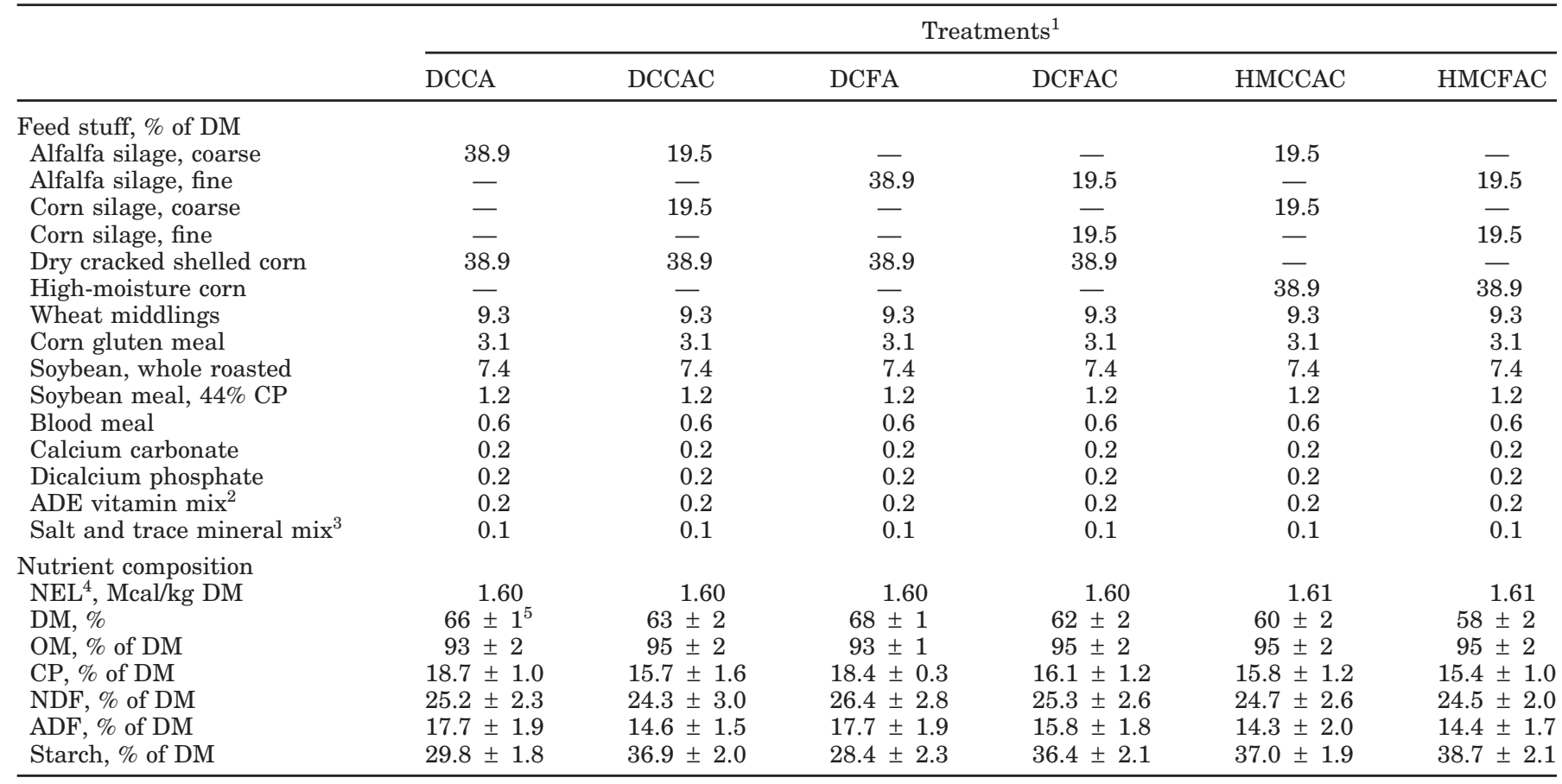

${ }^{1}$ Treatments: DCCA = dry cracked shelled corn and coarse alfalfa silage, DCCAC $=$ dry cracked shelled corn and coarse alfalfa/corn silage, DCFA = dry cracked shelled corn and fine alfalfa silage, DCFAC = dry cracked shelled corn and fine alfalfa/corn silage, HMCCAC = ground high-moisture shelled corn and coarse alfalfa/corn silage, HMCFAC = ground high-moisture shelled corn and fine alfalfa/corn silage.

${ }^{2} 3308 \mathrm{IU}$ of vitamin $\mathrm{A} / \mathrm{g}, 1103 \mathrm{IU}$ of vitamin $\mathrm{D} / \mathrm{g}$, and $11.03 \mathrm{IU}$ of vitamin $\mathrm{E} / \mathrm{g}$.

${ }^{3} 0.55 \% \mathrm{Mn}, 0.55 \% \mathrm{Zn}, 0.35 \% \mathrm{Fe}, 0.14 \% \mathrm{Cu}, 0.008 \% \mathrm{I}, 0.006 \%$ Se, and $0.002 \% \mathrm{Co}$.

${ }^{4}$ Based on tabular values.

${ }^{5}$ Mean \pm SD.

$550^{\circ} \mathrm{C}$ for $16 \mathrm{~h}$, and $\mathrm{CP}$ was determined by the microKjeldahl method (AOAC, 1990). The NDF fraction was determined using $\alpha$-amylase (Sigma no. A3306: Sigma Chemical Co., St. Louis, MO), sodium sulfite, and was corrected for ash content according to Mertens (1999) adapted for Ankom ${ }^{200}$ Fiber Analyzer (Ankom Technology, Fairport, NY). Acid detergent fiber was determined using the procedure described by Goering and Van Soest, (1970), adapted for Ankom ${ }^{200}$ Fiber Analyzer. Starch was determined using a colorimetric assay including a refined corn starch sample as described by Bal et al. (2000).

Particle size of forages and TMR were determined by dry-sieving using an oscillating screen particle size separator according to ASAE standard S424 (American National Standards Institute, 1988). Particle size of the corn grain was determined by dry-sieving according to ASAE (1995) standards.

\section{Ruminal pH and VFA Concentrations}

Ruminal $\mathrm{pH}$ was measured continuously for $3 \mathrm{~d}$ using an industrial electrode (Epoxy body sealed combination
pH electrode, no. 970061, Sensorex, CA) placed in the ventral sac of the rumen. A weight was attached to the electrode to prevent it from shifting in the rumen. Ruminal $\mathrm{pH}$ were recorded every minute and downloaded to a computer using the program LABTECH Notebook 7.5 (LABTECH, Andover, MA). Data acquisition was interrupted twice daily at time of milking. Time during which $\mathrm{pH}$ was $<5.8(\mathrm{~h} / \mathrm{d})$ and area under $5.8(\mathrm{~h} \times \mathrm{pH}$ units/d) were calculated. The area was calculated by adding the absolute value of negative deviations in $\mathrm{pH}$ from $\mathrm{pH} 5.8$ for each minute within a day. The number was divided by 60 in order to get the units $\mathrm{h} \times \mathrm{pH}$ units per day. Because of the substantial size of the dataset, $\mathrm{pH}$ values were averaged by hour before being analyzed as repeated measurements. Using this new dataset, mean $\mathrm{pH}$, lowest $\mathrm{pH}$ for each cow, and time to nadir were calculated.

Ruminal fluid was sampled 0,4 , and $8 \mathrm{~h}$ after the morning feeding $1 \mathrm{~d}$ each period. Approximately 100 $\mathrm{ml}$ of ruminal fluid were obtained as grab samples of digesta from the anterior dorsal, anterior ventral, medial ventral, posterior dorsal, and posterior ventral locations within the rumen, composited by cow, and 
strained through two layers of cheesecloth. Samples of $10 \mathrm{ml}$ were acidified with $0.5 \mathrm{ml}$ of $\mathrm{H}_{2} \mathrm{SO}_{4}$ and frozen for later VFA analysis. These samples were prepared as follows: 1) sample tubes were thawed and centrifuged at $2000 \times \mathrm{g}, 4^{\circ} \mathrm{C}$ for $\left.15 \mathrm{~min} ; 2\right)$ supernatant $(1 \mathrm{ml})$ was transferred into a microfuge tube, $0.2 \mathrm{ml}$ of $25 \%$ metaphosphoric acid was added, and the mixture was vortexed before incubating at room temperature for 30 min, and; 3) supernatant was transferred into a GLC sample vial for analysis by GLC (Auto System, Perkin Elmer, Shelton, CT) with GP $10 \%$ SP-1200/1\% $\mathrm{H}_{3} \mathrm{PO}_{4}$ on 80/100 Chromasorb WAW column packing (Supelco, Bellefonte, PA).

\section{Chewing Activities}

Eating and ruminating behaviors were monitored visually for a 24-h period during the days of ruminal $\mathrm{pH}$ monitoring. Eating and ruminating activities were noted every $5 \mathrm{~min}$, and each activity was assumed to persist for the entire 5-min interval. A meal was defined as at least one observation of eating activity occurring after at least 20 min without eating activity. This criterion was similar to the definition of eating used by Wangsness et al. (1976), who defined a meal as at least 1 min of eating activity after at least 20 min without eating activity. To estimate the time spent eating per kilogram of DMI, the actual intake for that day was used. A period of rumination was defined as at least 5 min of rumination occurring after at least 5 min without ruminating activity. When estimating the number of rumination periods per kilogram of DMI, or time spent ruminating per kilogram of NDF intake, the average daily intake measured in that period was used because time spent ruminating was assumed to reflect the DMI of previous days. Total time spent chewing was calculated as the total time spent eating and ruminating.

\section{Digestibility}

Lanthanum oxide in solution $(0.2 \mathrm{~g} / \mathrm{ml})$ was used as a marker to measure total tract digestibility (Hartnell and Satter, 1979) and was ruminally dosed at 12-h intervals for the last $14 \mathrm{~d}$ of each period to provide 0.8 $\mathrm{g}$ of La per cow per day. Fecal samples were collected every $6 \mathrm{~h}$ each day for $5 \mathrm{~d}$, but offset by $1 \mathrm{~h}$ daily so that the entire 24-h day was represented to account for possible diurnal variation. Fecal samples were dried, ground to pass a 1-mm screen of a Wiley mill, pooled by period for each cow, and ashed at $500^{\circ} \mathrm{C}$ for $16 \mathrm{~h}$. Concentrations of La were determined by direct current plasma emission spectroscopy (Spectra Metrics, Inc., subsidary of Beckman Instruments, Inc., Andover, MA;
Combs and Satter, 1992). Total tract nutrient digestibilities were calculated from fecal La concentration and nutrient concentrations in diets fed, orts, and feces.

\section{Microbial Protein Synthesis}

Urinary excretion of the purine derivatives allantoin and uric acid were used as an estimate of microbial $\mathrm{N}$ flow to the duodenum, and total urine output was estimated based on urinary creatinine concentration (Valadares et al., 1999). Spot samples of urine were obtained at 0500,1300 , and $2100 \mathrm{~h}$ on d 17 and at 0100 , 0900 , and $1700 \mathrm{~h}$ on d $18 \mathrm{in}$ each period. Aliquots of 20 $\mathrm{ml}$ were diluted with $90 \mathrm{ml}$ of tap water and stored at $-20^{\circ} \mathrm{C}$ for later analysis. Samples were composited by cow for each period and were analyzed for creatinine, allantoin, and uric acid. Estimated urine output (L/d) was calculated as BW $(\mathrm{kg}) \times$ creatinine excretion rate $(\mathrm{mg} / \mathrm{kg}$ of BW/d), divided by creatinine concentration $(\mathrm{mg} / \mathrm{L})$. One mean daily creatinine excretion rate of 29.0 $\mathrm{mg} / \mathrm{kg}$ of BW per day was used based on data from Valadares et al. (1999). Creatinine concentration in urine was determined using a commercial kit (Sigma no. 555; Sigma Chemical Co., St. Louis, MO). Concentration of allantoin in urine was determined colorimetrically using the method described by Chen and Gomes (1992); however, $1 M \mathrm{HCl}$ was used instead of $0.5 \mathrm{M} \mathrm{HCl}$ in the assay to keep $\mathrm{pH}<3$. Uric acid was determined colorimetrically using a diagnostic uric acid reagent (procedure no. 685, Sigma Diagnostics, St. Louis, MO). Final dilutions at time of analysis were 20,25, and 50 for creatinine, uric acid, and allantoin, respectively. Purine absorption and intestinal flow of microbial $\mathrm{N}$ was calculated using the assumptions and equations given by Chen and Gomes (1992). The quantitative relationship between absorption of microbial purines (X $\mathrm{mmol} / \mathrm{d}$ ) and excretion of purine derivatives in urine can be described by the following equation:

$$
\mathrm{Y}=0.85 \mathrm{X}+\left(0.0385 \mathrm{~W}^{0.75}\right) \text {, }
$$

where $\mathrm{W}^{0.75}$ represents the metabolic $\mathrm{BW}(\mathrm{kg})$ of the animal. The slope of 0.85 represents the recovery of absorbed purines as purine derivatives in urine. The component within parenthesis represents the net endogenous contribution of purine derivatives to total excretion after correction for the utilization of microbial purines by the animal. The following factors were used for the calculation of intestinal flow of microbial $\mathrm{N}$ ( $\mathrm{g}$ of $\mathrm{N} / \mathrm{d}$ ) from the microbial purines absorbed (X mmol/ d): digestibility of microbial purines was assumed to be 0.83 ; the $\mathrm{N}$ content of purines was $70 \mathrm{mg} \mathrm{N} / \mathrm{mmol}$; and the ratio of purine- $\mathrm{N}$ :total $\mathrm{N}$ in mixed rumen microbes 
was taken as 11.6:100. Thus, microbial $\mathrm{N}$ was calculated as:

$$
\begin{gathered}
\text { Microbial N supply }(\mathrm{g} / \mathrm{d})=(\mathrm{X} \times 70) / \\
(0.83 \times 0.116 \times 1000)=0.727 \times \mathrm{X}
\end{gathered}
$$

This assumes that the purine-to-protein ratio in mixed rumen microbes was unchanged by dietary treatment.

\section{Statistical Analysis}

Data on all variables, except ruminal VFA concentrations and ruminal $\mathrm{pH}$, were analyzed using the mixed model procedure in SAS (SAS, 1998); period and dietary treatment were fixed effects in the model, and period was used as a repeated measurement with first-order auto regressive covariance structure. This covariance structure provided the model with the best fit according to the Schwarz Bayesian Criterion. The random statement included square and cow within square. The model used is shown below:

$$
\mathrm{Y}_{\mathrm{ijkl}}=\mu+\mathrm{S}_{\mathrm{i}}+\mathrm{C}_{\mathrm{j}(\mathrm{i})}+\mathrm{P}_{\mathrm{k}}+\mathrm{T}_{1}+\mathrm{e}_{\mathrm{ijkl}}
$$

where $\mu$ = overall mean; $\mathrm{S}_{\mathrm{i}}=$ random effect of square (i $=1$ to 2$) ; C_{j(i)}=$ random effect of cow within square $(j=$ 1 to 6$) ; \mathrm{P}_{\mathrm{k}}=$ fixed effect of period analyzed as repeated measurements ( $\mathrm{k}=1$ to 6$) ; \mathrm{T}_{1}=$ fixed effect of dietary treatment $(\mathrm{l}=1$ to 6$)$; and $\mathrm{e}_{\mathrm{ijkl}}=$ random residual error, assumed to be normally distributed.

Ruminal VFA concentrations were analyzed using period and hour as repeated measurements. The model with the best fit according to the Schwarz Bayesian Criterion used a compound symmetry covariance structure for period and a first-order auto regressive covariance structure for hour. Ruminal VFA data were analyzed using the following model:

$$
\mathrm{Y}_{\mathrm{ijklm}}=\mu+\mathrm{S}_{\mathrm{i}}+\mathrm{C}_{\mathrm{j}(\mathrm{i})}+\mathrm{P}_{\mathrm{k}}+\mathrm{T}_{\mathrm{l}}+\mathrm{H}_{\mathrm{m}}+\mathrm{e}_{\mathrm{ijk} \mathrm{lm}},
$$

where $\mu$ = overall mean; $\mathrm{S}_{\mathrm{i}}=$ random effect of square (i $=1$ to 2$) ; \mathrm{C}_{\mathrm{j}(\mathrm{i})}=$ random effect of cow within square $(\mathrm{j}=$ 1 to 6$) ; \mathrm{P}_{\mathrm{k}}=$ fixed effect of period analyzed as repeated measurements ( $\mathrm{k}=1$ to 6$) ; \mathrm{T}_{1}=$ fixed effect of dietary treatment ( $\mathrm{l}=1$ to 6$) ; \mathrm{H}_{\mathrm{m}}=$ fixed effect of hours post feeding analyzed as repeated measurements $(\mathrm{m}=1$ to 3 ); and $\mathrm{e}_{\mathrm{ijk} \mathrm{km}}=$ random residual error, assumed to be normally distributed. No significant interactions were found between hours post feeding and main effects; therefore, these terms were left out of the model.

Before ruminal $\mathrm{pH}$ data were analyzed, $\mathrm{pH}$ values were averaged by hour in order to reduce the number of observations. One day of observations started at the first feeding at $0730 \mathrm{~h}$ and ran until the next morning feeding. Even though cows were not fed restrictively, feeding at 0730 and $1930 \mathrm{~h}$ resulted in a specific biphasic diurnal pattern in $\mathrm{pH}$. Therefore, feeding (first and second) was introduced as a variable in the model, creating a model with repeated measures on four levels: period, day, feeding, and hour post feeding $(12 \mathrm{~h})$. The model with the best fit according to the Schwarz Bayesian Criterion was a model using a compound symmetry covariance structure for period, day, and feeding, and a first-order auto regressive covariance structure for hours post feeding. Only main effects and two factor interactions were included in the fixed effects portion of the model, as three- and four-factor interactions were not significant. The model was:

$$
\begin{gathered}
\mathrm{Y}_{\mathrm{ijklmno}}=\mu+\mathrm{S}_{\mathrm{i}}+\mathrm{C}_{\mathrm{j}(\mathrm{i})}+\mathrm{P}_{\mathrm{k}}+\mathrm{T}_{1}+\mathrm{D}_{\mathrm{m}}+(\mathrm{D} \times \mathrm{T})_{\mathrm{ml}}+\mathrm{E}_{\mathrm{n}} \\
+(\mathrm{E} \times \mathrm{T})_{\mathrm{nl}}+(\mathrm{D} \times \mathrm{E})_{\mathrm{mn}}+\mathrm{H}_{\mathrm{o}}+(\mathrm{H} \times \mathrm{T})_{\mathrm{ol}}+(\mathrm{H} \times \mathrm{D})_{\mathrm{om}} \\
+(\mathrm{H} \times \mathrm{E})_{\mathrm{on}}+\mathrm{e}_{\mathrm{ijkl} \text { lmno }},
\end{gathered}
$$

where $\mu$ = overall mean; $\mathrm{S}_{\mathrm{i}}=$ random effect of square (i $=1$ to 2$) ; \mathrm{C}_{\mathrm{j}(\mathrm{i})}=$ random effect of cow within square $(\mathrm{j}=$ 1 to 6$) ; P_{k}=$ fixed effect of period analyzed as repeated measurements ( $\mathrm{k}=1$ to 6$) ; \mathrm{T}_{1}=$ fixed effect of dietary treatment ( $1=1$ to 6$) ; D_{m}=$ fixed effect of day of sampling analyzed as repeated measurements ( $\mathrm{m}=1$ to 3$) ;(\mathrm{D} \times$ $T)_{m l}=$ fixed effect of interaction of $D_{m}$ and $T_{1} ; E_{n}=$ fixed effect of feeding analyzed as repeated measurement ( $\mathrm{n}$ $=1$ to 2$) ;(\mathrm{E} \times \mathrm{T})_{\mathrm{nl}}=$ fixed effect of interaction of $\mathrm{E}_{\mathrm{n}}$ and $\mathrm{T}_{1} ;(\mathrm{D} \times \mathrm{E})_{\mathrm{mn}}=$ fixed effect of interaction of $\mathrm{D}_{\mathrm{m}}$ and $\mathrm{E}_{\mathrm{n}} ; \mathrm{H}_{\mathrm{o}}=$ fixed effect of hours post feeding analyzed as repeated measurements $(\mathrm{o}=1$ to 12$) ;(\mathrm{H} \times \mathrm{T})_{\mathrm{ol}}=$ fixed effect of interaction of $\mathrm{H}_{\mathrm{o}}$ and $\mathrm{M}_{1} ;(\mathrm{H} \times \mathrm{D})_{\mathrm{om}}$ = fixed effect of interaction of $\mathrm{H}_{\mathrm{o}}$ and $\mathrm{D}_{\mathrm{m}} ;(\mathrm{H} \times \mathrm{E})_{\mathrm{om}}=$ fixed effect of interaction of $\mathrm{H}_{\mathrm{o}}$ and $\mathrm{E}_{\mathrm{m}}$; and $\mathrm{e}_{\mathrm{ijklmno}}=$ random residual error, assumed to be normally distributed.

Contrasts were built to test effect of forage particle size (DCCA, DCCAC, and HMCCAC vs. DCFA, DCFAC, and HMCFAC), effect of level of RFC (DCCAC and DCFAC vs. HMCCAC and HMCFAC), effect of forage source (DCCA and DCFA vs. DCCAC and DCFAC), interaction between forage particle size and level of RFC (DCCAC and HMCFAC vs. DCFAC and HMCCAC), and interaction between forage particle size and forage source (DCCA and DCFAC vs. DCCAC and DCFA). Based on these contrasts, the effect of level of RFC and the interaction between forage particle size and RFC was tested only for diets containing a mix of alfalfa silage and corn silage. Also, the effect of forage source and the interaction between forage particle size and forage source was tested only within diets containing DC. Significance was declared at $P \leq 0.05$. A trend was considered to exist if $0.05<P \leq 0.10$. All reported values are least square means unless otherwise stated. 
Table 4. Effects of dietary treatments on intake.

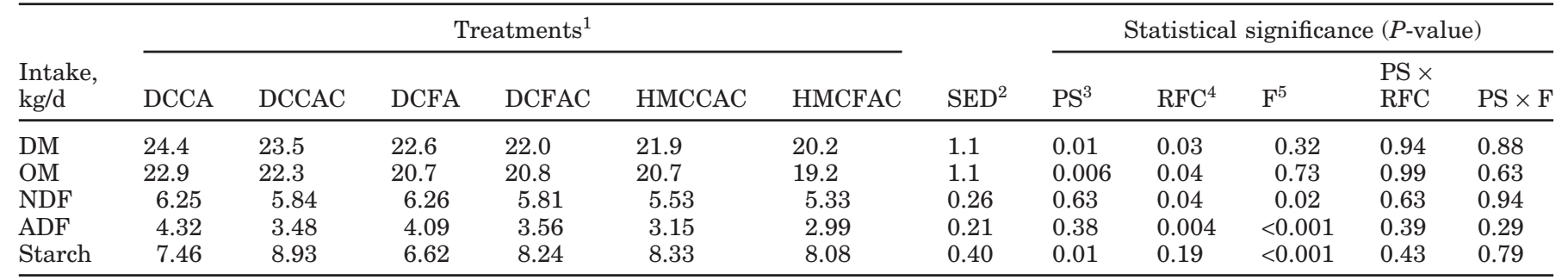

${ }^{1}$ Treatments: DCCA = dry cracked shelled corn and coarse alfalfa silage, DCCAC = dry cracked shelled corn and coarse alfalfa/corn silage, DCFA $=$ dry cracked shelled corn and fine alfalfa silage, DCFAC $=$ dry cracked shelled corn and fine alfalfa/corn silage, HMCCAC $=$ ground high-moisture shelled corn and coarse alfalfa/corn silage, HMCFAC = ground high-moisture shelled corn and fine alfalfa/corn silage.

${ }^{2} \mathrm{SED}=$ standard error of difference.

${ }^{3} \mathrm{PS}=$ forage particle size.

${ }^{4} \mathrm{RFC}=$ ruminally fermentable carbohydrate.

${ }^{5} \mathrm{~F}=$ forage source.

\section{RESULTS AND DISCUSSION}

\section{Feed Particle Size and Intakes}

Intakes of DM, OM, and nutrients are shown in Table 4. Decreasing forage particle size decreased DMI (23.3 vs. $21.6 \mathrm{~kg}$ ) and organic matter intake (OMI) (22.0 vs. $20.2 \mathrm{~kg}$ ). This is in contrast to a previous study (Krause et al., 2002a), where similar diets were fed and no significant effect of forage particle size was found on DMI and OMI. In the previous study, the difference in mean particle size of the coarse and fine alfalfa silage fed (13.6 vs. $3.7 \mathrm{~mm}$, respectively) was greater than in the current study $(5.3$ and $5.6 \mathrm{~mm}$ vs. 2.7 and $2.8 \mathrm{~mm}$, for coarse alfalfa silage, coarse corn silage, fine alfalfa silage, and fine corn silage, respectively). Also, the present study had higher levels of dietary starch, which might increase a possible negative effect of decreasing forage particle size. Despite a 2-kg lower DMI in the current study, average daily intake of starch was 7.9 $\mathrm{kg}$ in the current study vs. $6.6 \mathrm{~kg}$ in the previous study. Mooney and Allen (1997) found that decreasing alfalfa silage mean particle size from 11.4 to $5.8 \mathrm{~mm}$ increased DMI. Fischer et al. (1994) also reported increased DMI for multiparous cows fed a TMR with $45 \%$ forage when mean particle size of alfalfa silage was decreased from 9.57 to $3.02 \mathrm{~mm}$. In contrast, several other studies (Shaver et al., 1986; Woodford et al., 1986) found no effect of decreasing forage particle size on intake in diets containing above $40 \%$ concentrate.

Increasing the level of RFC by replacing DC with HMC decreased DMI (22.8 vs. $21.0 \mathrm{~kg}$ ) and OMI (21.5 vs. $20.0 \mathrm{~kg}$ ). This is in agreement with a previous study where HMC replaced DC in similar diets fed to midlactation cows (Krause et al., 2002a). Increasing the starch content of the diet by partially replacing alfalfa silage with corn silage did not affect DMI or OMI but did decrease NDF and ADF intake and increase starch in- take. The corn silage, which replaced alfalfa silage, had a lower ADF content and a higher starch content than the alfalfa silage, and the observed changes in intake of these nutrients were, therefore, expected. Replacing DC with HMC also decreased NDF and ADF intake. Decreasing forage particle size decreased intake of starch probably because of lower DMI. The fact that starch intake decreased, but NDF intake remained unchanged when forage particle size decreased, indicates that cows sorted against NDF and in favor of starch, but that this sorting diminished when the forage was finely chopped. Intake of starch was $>8 \mathrm{~kg} / \mathrm{d}$ for diets containing corn silage, and starch intake ranged from 29 to $40 \%$ of DMI across all diets.

\section{Milk Production}

Decreasing forage particle size tended to increase milk production ( 41.0 vs. $42.3 \mathrm{~kg} ; P=0.08$ ) despite the decrease in DMI (Table 5). Clark and Armentano (1998) also found that milk yield increased linearly when mean particle size of alfalfa silage decreased from 7.2 to 5.4 $\mathrm{mm}$. Milk yield was not affected by level of RFC even though DMI was $1.8 \mathrm{~kg}$ lower for diets containing HMC compared to the similar diets containing DC. However, yield of ECM was decreased when HMC replaced DC $(35.2$ vs. $32.5 \mathrm{~kg})$. Yield of ECM was also affected by forage particle size, but this effect depended on forage source, with ECM increasing when forage particle size was reduced for diets where alfalfa silage was the only forage (34.9 vs. $37.4 \mathrm{~kg}$ ) and decreasing for diets containing both alfalfa and corn silage ( 35.9 vs. $34.5 \mathrm{~kg})$. A possible explanation for the interaction between forage particle size and forage source could be that digestibility of alfalfa silage was increased to a greater degree than corn silage when particle size was reduced. Grinding or chopping forage very finely increases the surface 
Table 5. Effects of dietary treatments on milk production and composition.

\begin{tabular}{|c|c|c|c|c|c|c|c|c|c|c|c|c|}
\hline \multirow[b]{2}{*}{$\begin{array}{l}\text { Dependent } \\
\text { production variable }\end{array}$} & \multicolumn{6}{|c|}{ Treatments $^{1}$} & \multirow[b]{2}{*}{$\mathrm{SED}^{2}$} & \multicolumn{5}{|c|}{ Statistical significance ( $P$-value) } \\
\hline & DCCA & DCCAC & DCFA & DCFAC & HMCCAC & HMCFAC & & $\mathrm{PS}^{3}$ & $\mathrm{RFC}^{4}$ & $\mathrm{~F}^{5}$ & $\begin{array}{l}\mathrm{PS} \times \\
\mathrm{RFC}\end{array}$ & $\begin{array}{l}P S \\
\times \mathrm{F}\end{array}$ \\
\hline Milk & 40.0 & 41.5 & 42.7 & 42.0 & 41.8 & 42.1 & 1.1 & 0.08 & 0.75 & 0.65 & 0.87 & 0.17 \\
\hline Fat & 1.31 & 1.34 & 1.44 & 1.22 & 1.10 & 1.02 & 0.06 & 0.52 & $<0.001$ & 0.04 & 0.65 & 0.007 \\
\hline Protein & 1.14 & 1.20 & 1.20 & 1.20 & 1.19 & 1.19 & 0.04 & 0.32 & 0.68 & 0.26 & 0.88 & 0.98 \\
\hline Lactose & 1.95 & 2.03 & 2.09 & 2.06 & 2.04 & 2.04 & 0.06 & 0.10 & 0.94 & 0.59 & 0.70 & 0.45 \\
\hline ECM/DMI & 1.43 & 1.51 & 1.68 & 1.61 & 1.51 & 1.60 & 0.07 & 0.001 & 0.91 & 0.94 & 0.92 & 0.13 \\
\hline \multicolumn{13}{|l|}{ Composition, \% } \\
\hline Fat & 3.32 & 3.19 & 3.38 & 2.89 & 2.71 & 2.43 & 0.14 & 0.04 & $<0.001$ & 0.004 & 0.92 & 0.08 \\
\hline Protein & 2.86 & 2.92 & 2.83 & 2.89 & 2.85 & 2.83 & 0.04 & 0.23 & 0.02 & 0.05 & 0.80 & 0.98 \\
\hline Lactose & 4.85 & 4.88 & 4.88 & 4.89 & 4.86 & 4.84 & 0.03 & 0.74 & 0.04 & 0.18 & 0.34 & 0.45 \\
\hline SNF & 8.67 & 8.76 & 8.67 & 8.75 & 8.67 & 8.63 & 0.05 & 0.54 & 0.004 & 0.02 & 0.71 & 0.83 \\
\hline
\end{tabular}

${ }^{1}$ Treatments: DCCA = dry cracked shelled corn and coarse alfalfa silage, DCCAC $=$ dry cracked shelled corn and coarse alfalfa/corn silage, DCFA = dry cracked shelled corn and fine alfalfa silage, DCFAC = dry cracked shelled corn and fine alfalfa/corn silage, HMCCAC = ground high-moisture shelled corn and coarse alfalfa/corn silage, HMCFAC = ground high-moisture shelled corn and fine alfalfa/corn silage.

${ }^{2} \mathrm{SED}=$ standard error of difference.

${ }^{3} \mathrm{PS}=$ forage particle size.

${ }^{4} \mathrm{RFC}=$ ruminally fermentable carbohydrate.

${ }^{5} \mathrm{~F}=$ forage source.

${ }^{6} \mathrm{SNF}=$ solids non-fat.

${ }^{7} \mathrm{ECM}=$ energy-corrected milk.

available for microbial attack and, thus, could allow a more rapid and complete ruminal degradation. However, the measured total tract digestibilities (Table 6) do not support this hypothesis. Efficiency of milk production, expressed as a kilogram of ECM produced per kilogram of DMI, increased with decreasing forage particle size.

Percentages of milk fat were low, with none of the dietary treatments resulting in milk fat percentages $>3.5 \%$ and three of the treatments resulting in milk fat percentages $<3.0 \%$. For the two diets containing HMC, the percentage of milk fat was lower than the percent- age of true protein. Percentage of milk fat decreased from 3.07 to $2.90 \%$ when forage particle size decreased, but this effect tended $(P=0.08)$ to be greatest for diets containing a mix of alfalfa and corn silage. Increasing the level of RFC also decreased milk fat percentage (3.04 vs. $2.57 \%$ ). An earlier study (Krause et al., 2002a) found no effect on milk fat percentage when replacing DC with HMC. However, the level of dietary starch was lower than in the current study (27.3 vs. $36.7 \%)$. Diets in the previous study were based on alfalfa silage and not on a mix of alfalfa and corn silage, as in the current study. Oba and Allen (2000) reported a depression in

Table 6. Effects of dietary treatments on total tract digestibilities.

\begin{tabular}{|c|c|c|c|c|c|c|c|c|c|c|c|c|}
\hline \multirow[b]{2}{*}{$\begin{array}{l}\text { Digestibilities, } \\
\%\end{array}$} & \multicolumn{6}{|c|}{ Treatments $^{1}$} & \multirow[b]{2}{*}{$\mathrm{SED}^{2}$} & \multicolumn{5}{|c|}{ Statistical significance ( $P$-value $)$} \\
\hline & DCCA & DCCAC & DCFA & DCFAC & HMCCAC & HMCFAC & & $\mathrm{PS}^{3}$ & $\mathrm{RFC}^{4}$ & $\mathrm{~F}^{5}$ & $\begin{array}{l}\mathrm{PS} \times \\
\mathrm{RFC}\end{array}$ & $\mathrm{PS} \times \mathrm{F}$ \\
\hline $\mathrm{OM}$ & 66.9 & 68.9 & 64.2 & 63.0 & 70.0 & 71.4 & 2.3 & 0.08 & 0.005 & 0.82 & 0.02 & 0.32 \\
\hline NDF & 45.7 & 40.6 & 42.7 & 41.0 & 43.5 & 41.5 & 3.9 & 0.49 & 0.56 & 0.21 & 0.67 & 0.53 \\
\hline $\mathrm{ADF}$ & 44.6 & 36.4 & 34.9 & 31.9 & 38.9 & 39.6 & 3.2 & 0.01 & 0.02 & 0.01 & 0.24 & 0.18 \\
\hline Starch & 88.4 & 88.8 & 86.5 & 88.9 & 93.7 & 93.1 & 1.5 & 0.40 & $<0.001$ & 0.21 & 0.74 & 0.37 \\
\hline
\end{tabular}

${ }^{1}$ Treatments: DCCA = dry cracked shelled corn and coarse alfalfa silage, DCCAC = dry cracked shelled corn and coarse alfalfa/corn silage, DCFA $=$ dry cracked shelled corn and fine alfalfa silage, DCFAC $=$ dry cracked shelled corn and fine alfalfa/corn silage, $\mathrm{HMCCAC}=$ ground high-moisture shelled corn and coarse alfalfa/corn silage, HMCFAC = ground high-moisture shelled corn and fine alfalfa/corn silage.

${ }^{2} \mathrm{SED}=$ standard error of difference.

${ }^{3}$ forage particle size.

${ }^{4} \mathrm{RFC}=$ ruminally fermentable carbohydrate.

${ }^{5} \mathrm{~F}=$ forage source. 
percentage of milk fat when HMC replaced DC in high starch diets (31\%) but no difference when diets contained $21 \%$ starch.

Replacing half of the alfalfa silage with corn silage decreased percentage of milk fat from 3.35 to $3.04 \%$. Dhiman and Satter (1997) reported a decrease in percentage of milk fat when corn silage replaced two-thirds of alfalfa silage in diets containing $50 \%$ forage (DM basis) fed to multiparous cows, but percentage of milk fat was unaffected when corn silage replaced one-third of alfalfa silage. Total fat yield was also decreased when we replaced half of the alfalfa silage with corn silage (1.37 vs. $1.28 \mathrm{~kg}$ ) and was less for cows fed HMC than for cows fed DC diets (1.28 vs. $1.06 \mathrm{~kg})$. Decreasing forage particle size decreased fat yield for cows fed diets containing both alfalfa and corn silage but not for cows fed alfalfa silage as the sole source of forage.

Percentage of protein increased when corn silage partially replaced alfalfa silage (2.84 vs. $2.90 \%)$, but decreased from 2.90 to $2.84 \%$ when level of RFC was increased by replacing DC with HMC. Protein yield was not affected by any of the dietary treatments. Percentage of lactose decreased from 4.89 to $4.85 \%$ when DC was replaced by HMC, and yield of lactose increased 50 $\mathrm{g}$ when forage particle size was decreased. Percentage of SNF decreased from 8.75 to $8.65 \%$ when HMC replaced $\mathrm{DC}$ and increased when alfalfa silage was partially replaced by corn silage ( 8.67 vs. $8.75 \%$ ).

\section{Digestibilities}

Total tract digestibility of OM tended to decrease $(P$ $=0.08$ ) when forage particle size was decreased (Table $6)$. It is somewhat surprising that milk production increased with decreasing particle size considering the concurrent decrease in DMI and the trend towards a decrease in OM digestibility. Replacing DC with HMC increased DM digestibility from 66.7 to $68.5 \%$, OM digestibility from 65.9 to $70.7 \%$ and starch digestibility from 88.9 to $93.4 \%$. This finding is consistent with several studies (Knowlton et al., 1998; Ying et al., 1998; Krause et al., 2002a). The observed increase in DM and OM digestibility when HMC replaced DC was accounted for by the increase in starch digestibility. Total tract digestibility of NDF was not affected by dietary treatments, whereas digestibility of $\mathrm{ADF}$ decreased from 40.0 to $35.5 \%$ when forage particle size was decreased. Depressed fiber digestibility has been reported when forage particle size is reduced (Shaver et al., 1986; Woodford and Murphy, 1988; Le Liboux and Peyraud, 1999), but no effect of reducing forage particle size on fiber digestibility was found by Krause et al. (2002a). Partially replacing alfalfa silage with corn silage also decreased ADF digestibility, whereas replacing DC with $\mathrm{HMC}$ increased total tract digestibility of $\mathrm{ADF}$. We have no explanation for this increase in ADF digestibility when level of RFC was increased. Mean ruminal $\mathrm{pH}$ for the six diets (Table 10) are below the threshold where fiber digestion is inhibited in vitro (Calsamiglia et al., 2002); however, Varel and Kreikemeier (1995) concluded that in vitro digestion methods do not adequately reflect the effect of low rumen $\mathrm{pH}$ on NDF digestion in the rumen.

\section{Microbial Yield}

Urinary purine derivative excretion and microbial $\mathrm{N}$ production estimates are shown in Table 7. Daily excretion of the purine derivative uric acid was not affected by any of the dietary treatments, but the excre-

Table 7. Effects of dietary treatments on purine derivative excretion.

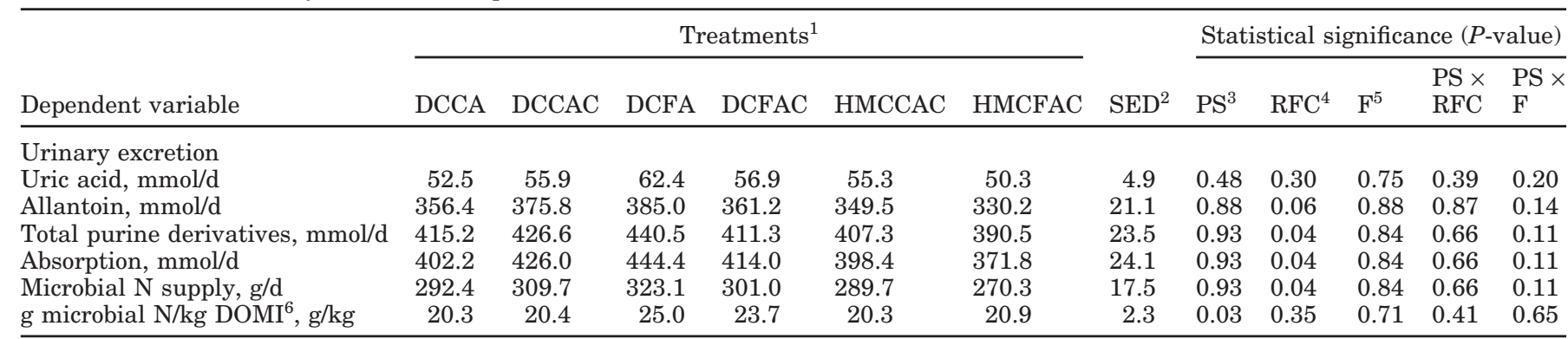

${ }^{1}$ Treatments: DCCA = dry cracked shelled corn and coarse alfalfa silage, DCCAC = dry cracked shelled corn and coarse alfalfa/corn silage, DCFA $=$ dry cracked shelled corn and fine alfalfa silage, DCFAC $=$ dry cracked shelled corn and fine alfalfa/corn silage, HMCCAC $=$ ground high moisture shelled corn and coarse alfalfa/corn silage, HMCFAC = ground high-moisture shelled corn and fine alfalfa/corn silage .

${ }^{2} \mathrm{SED}=$ standard error of difference.

${ }^{3} \mathrm{PS}=$ forage particle size.

${ }^{4} \mathrm{RFC}=$ ruminally fermentable carbohydrate.

${ }^{5} \mathrm{~F}=$ forage source.

${ }^{6} \mathrm{DOMI}=$ digestible organic matter intake. 
tion of allantoin tended to decrease $(P=0.06)$ when HMC replaced DC. Total excretion of purine derivatives was lower for HMC diets than for DC diets, and consequently, the calculated intestinal flow of microbial $\mathrm{N}$ decreased from 305.3 to $280.0 \mathrm{~g} / \mathrm{d}$ when HMC replaced DC. The microbial $\mathrm{N}$ supplies estimated in the current study are lower than reported by Valadares et al. (1999), who estimated microbial $\mathrm{N}$ supply according to the same procedure from diets based on alfalfa silage and high-moisture ear corn and found an average microbial N supply of $368.8 \mathrm{~g} / \mathrm{d}$. A $16 \%$ increase in microbial $\mathrm{N}$ supply was found in an earlier study (Krause et al., 2002a) when HMC replaced DC. However, the diets were based solely on alfalfa silage, and not a mix of alfalfa and corn silage, and also contained $18.7 \% \mathrm{CP}$ vs. $15.6 \%$ for HMC diets fed in the present study. The diets based on a mix of alfalfa and corn silage contained high levels of dietary starch; therefore, a further increase of fermentability by replacing DC with HMC might not increase microbial protein synthesis. Also, DMI of HMC diets was $1.8 \mathrm{~kg}$ lower than DMI of DC diets. When estimated microbial N production was expressed per kilogram of digestible OMI (DOMI), HMC diets yielded similar amounts of microbial N/kg DOMI as DC diets. However, this efficiency is expressed per $\mathrm{kg}$ of total tract DOMI and not per $\mathrm{kg}$ of OM digested in the rumen. Replacing DC with HMC should increase amount of OM digested in the rumen, and one would, therefore, expect an increase in microbial $\mathrm{N}$ production assuming adequate availability of nitrogen. However, mean ruminal $\mathrm{pH}$ was lower and time and area $<\mathrm{pH}$ 5.8 higher (Table 10) when HMC replaced DC. Decreasing $\mathrm{pH}$ in in vitro incubations has been reported to decrease utilization of mixed substrates and efficiency of microbial protein production (Strobel and Russell, 1986). Decreasing forage particle size increased estimated amount of microbial $\mathrm{N}$ per kilogram of digestible OMI from 20.3 to $23.2 \mathrm{~g}$. This could possibly be due to increased passage of small particles and attached microbes from the rumen. However, rate of passage was not measured in this study.

\section{Chewing Activities}

Chewing activities are reported in Table 8. Time spent eating ranged from 3.4 to $4.6 \mathrm{~h} / \mathrm{d}$. Time spent eating was affected by forage particle size; eating time was $4.2 \mathrm{~h}$ for coarse forage diets and $3.6 \mathrm{~h}$ for finely chopped forage diets. This difference in time spent eating was not only caused by the lower DMI for diets containing finely chopped forage, since time spent eating per kilogram of DMI also decreased when forage particle size was decreased (11.0 vs. $9.9 \mathrm{~min}$ ). This is in agreement with the observations of Mooney and Allen
(1997), who reported that long-cut alfalfa silage (11.4 $\mathrm{mm}$ ) was ingested more slowly and required more chews per unit of DM compared to short-cut alfalfa silage $(5.8 \mathrm{~mm})$. Number of meals increased from 10.4 to 11.5 per day when level of RFC was increased, but the duration of each meal remained unchanged. DMI was lower for HMC diets compared to DC diets, and number of meals per kilogram DMI per day increased from 0.46 to 0.55 when level of RFC was increased. The effect of decreasing forage particle size on number of meals depended on type of forage. When forage particle size was decreased in DC and alfalfa silage diets, number of meals increased, but the opposite was true for DC and mixed forage diets.

Time spent ruminating ranged from 5.1 to $7.7 \mathrm{~h} / \mathrm{d}$. Time spent ruminating per day decreased from 7.3 to $5.7 \mathrm{~h}$ when forage particle size was decreased. The greater rumination activity for the coarse silage suggests that particle size was greater even after initial chewing and swallowing. Replacing part of the alfalfa silage with corn silage increased time spent ruminating from 5.9 to $6.6 \mathrm{~h} / \mathrm{d}$. When time spent ruminating was expressed per kilogram of DMI, decreasing forage particle size decreased time spent ruminating from 19.2 to $16.3 \mathrm{~min}$. Replacing DC with HMC increased time spent ruminating per kilogram of DMI from 18.0 to $20.2 \mathrm{~min}$, as did replacing part of the alfalfa silage with corn silage (15.1 vs. $17.9 \mathrm{~min}$ ). Both forage particle size, corn processing, and source of forage affected time spent ruminating per kilogram of NDF intake. Decreasing forage particle size decreased time spent ruminating per kilogram of NDF intake from 76.4 to $62.3 \mathrm{~min}$. Increasing level of ruminally fermentable carbohydrates by replacing DC with HMC tended $(P=0.06)$ to increase time spent ruminating per kilogram of NDF intake from 71.1 to $80.0 \mathrm{~min}$. Similar results were reported by Krause et al. (2002b), when particle size of alfalfa silage was reduced, and by Woodford and Murphy (1988), when the ratio of alfalfa pellets to alfalfa silage was increased in diets fed to early lactation cows. Assuming forage was the only component of the diet that would stimulate rumination, the trend towards an increase in rumination time per kilogram of NDF intake when RFC was increased indicates that the cows adapted to the increase in RFC by increasing rumination activity. An increase in saliva flow as a result of more time spent ruminating could increase the low ruminal $\mathrm{pH}$ or enhance particulate and fluid movement from the rumen. Increasing level of dietary starch by partially replacing alfalfa silage by corn silage also increased time spent ruminating per kilogram of NDF intake ( 56.9 vs. $71.1 \mathrm{~min}$ ). This may also be due to the increased level of fermentable carbohydrates in the diet 
Table 8. Effects of dietary treatments on chewing behavior.

\begin{tabular}{|c|c|c|c|c|c|c|c|c|c|c|c|c|}
\hline \multirow[b]{2}{*}{ Dependent variable } & \multicolumn{6}{|c|}{ Treatments $^{1}$} & \multirow[b]{2}{*}{$\mathrm{SED}^{2}$} & \multicolumn{5}{|c|}{ Statistical significance ( $P$-value) } \\
\hline & DCCA & DCCAC & DCFA & DCFAC & HMCCAC & HMCFAC & & $\mathrm{PS}^{3}$ & $\mathrm{RFC}^{4}$ & $\mathrm{~F}^{5}$ & $\begin{array}{l}\mathrm{PS} \times \\
\mathrm{RFC}\end{array}$ & $\begin{array}{l}\mathrm{PS} \times \\
\mathrm{F}\end{array}$ \\
\hline Time, $\mathrm{min} / \mathrm{d}$ & 278 & 245 & 229 & 215 & 240 & 202 & 13 & $<0.001$ & 0.31 & 0.01 & 0.63 & 0.29 \\
\hline Time/DMI, min/kg & 11.1 & 10.5 & 9.9 & 9.8 & 11.4 & 10.1 & 0.8 & 0.03 & 0.29 & 0.52 & 0.62 & 0.69 \\
\hline Meals, $\mathrm{d}^{-1}$ & 10.7 & 11.1 & 11.6 & 9.7 & 11.1 & 11.5 & 0.7 & 0.71 & 0.03 & 0.11 & 0.11 & 0.01 \\
\hline Duration of meal, min & 29.4 & 28.1 & 22.9 & 29.5 & 26.9 & 39.1 & 10.0 & 0.68 & 0.55 & 0.71 & 0.45 & 0.57 \\
\hline Time, $\mathrm{min} / \mathrm{d}$ & 402 & 451 & 306 & 346 & 461 & 373 & 25 & $<0.001$ & 0.31 & 0.02 & 0.63 & 0.80 \\
\hline Time/DMI, $\mathrm{min} / \mathrm{kg}$ & 16.6 & 19.6 & 13.6 & 16.4 & 21.5 & 18.8 & 1.5 & $<0.001$ & 0.04 & 0.007 & 0.80 & 0.91 \\
\hline Time/NDF intake, $\mathrm{min} / \mathrm{kg}$ & 65.4 & 79.3 & 98.4 & 62.6 & 84.5 & 75.9 & 6.4 & $<0.001$ & 0.06 & 0.003 & 0.44 & 0.92 \\
\hline Periods, $\mathrm{d}^{-1}$ & 17.0 & 16.5 & 13.0 & 15.1 & 17.0 & 14.4 & 1.0 & $<0.001$ & 0.89 & 0.25 & 0.41 & 0.06 \\
\hline Duration of period, min & 24.1 & 27.9 & 23.1 & 22.7 & 27.6 & 26.3 & 1.5 & 0.007 & 0.12 & 0.12 & 0.07 & 0.05 \\
\hline \multicolumn{13}{|l|}{ Chewing } \\
\hline Time, $\mathrm{min} / \mathrm{d}$ & 678 & 703 & 530 & 560 & 702 & 575 & 34 & $<0.001$ & 0.76 & 0.26 & 0.74 & 0.91 \\
\hline
\end{tabular}

${ }^{1}$ Treatments: DCCA = dry cracked shelled corn and coarse alfalfa silage, DCCAC = dry cracked shelled corn and coarse alfalfa/corn silage, DCFA = dry cracked shelled corn and fine alfalfa silage, DCFAC $=$ dry cracked shelled corn and fine alfalfa/corn silage, HMCCAC $=$ ground high-moisture shelled corn and coarse alfalfa/corn silage, HMCFAC = ground high-moisture shelled corn and fine alfalfa/corn silage.

${ }^{2} \mathrm{SED}=$ standard error of difference.

${ }^{3} \mathrm{PS}=$ forage particle size.

${ }^{4} \mathrm{RFC}=$ ruminally fermentable carbohydrate.

${ }^{5} \mathrm{~F}=$ forage source.

or due to different structure or composition of corn plant NDF compared to NDF from alfalfa.

The decrease in time spent ruminating observed when forage particle size was decreased was caused by a decrease in number of rumination periods per day (16.8 vs.14.1) and a decrease in the duration of rumination periods ( $26.5 \mathrm{vs} .24 .1 \mathrm{~min}$ ). The effect of decreasing forage particle size on duration of rumination periods depended on type of forage and tended $(P=0.07)$ to depend on level of RFC. When forage particle size was decreased in DC and alfalfa silage diets, duration of rumination periods remained the same, whereas duration decreased for DC and mixed forage diets. For the mixed forage diets, duration of rumination periods decreased when forage particle length was decreased in DC diets but was unchanged in HMC diets.

Total time spent chewing per day ranged from 8.8 to $11.7 \mathrm{~h}$ and decreased from 11.6 to $9.2 \mathrm{~h}$ when forage particle size was decreased. Time spent chewing per kilogram of DMI decreased with decreasing forage particle size (30.5 vs. $26.4 \mathrm{~min})$ and tended to increase when part of the alfalfa silage was replaced by corn silage $(P=0.07)$. Chewing activity is the animal response associated with physical effectiveness of the NDF fraction (Mertens, 1997). When time spent chewing was expressed as per kilogram of NDF intake, fine silage was $82 \%$ as effective at promoting chewing as coarse silage in this study (calculated as 100\% times average time spent chewing per kilogram of NDF intake for diets based on fine silage divided by average time spent chewing per kilogram of NDF intake for diets based on coarse silage). Thus, reducing forage particle size decreased the physically effective factor of forage NDF. However, time spent chewing per kilogram of $\mathrm{NDF}$ intake was not only related to forage particle size, indicating that physical effectiveness of forages is affected by other dietary components such as forage source and fermentability of the starch source.

The daily eating and rumination pattern averaged across dietary treatments is shown in Figure 1. Eating activity was highest during the hour after the morning feeding $(38 \mathrm{~min} / \mathrm{h})$, and cows spent more time eating during the $12 \mathrm{~h}$ after the morning feeding compared to the $12 \mathrm{~h}$ after the evening feeding (2.6 vs. $1.3 \mathrm{~h}$ ). Cows were fed twice daily, but the majority of the feed was allocated at the morning feeding, which could explain the higher eating activity during the $12 \mathrm{~h}$ after the morning feeding. For rumination activity, the opposite was true: Cows spent $2.9 \mathrm{~h}$ ruminating during the 12 $\mathrm{h}$ after the morning feeding and $3.6 \mathrm{~h}$ after the evening feeding.

\section{Ruminal VFA Concentrations}

Total ruminal VFA concentration was affected by hour of sampling $(P<0.001)$ and was $137.6,167.6$, and $158.5 \mathrm{mM}$ for 0,4 , and $8 \mathrm{~h}$ after the morning feeding, respectively $(\mathrm{SED}=3.6)$. The same pattern in relation to sampling time was found for the individual VFA (data not shown). No diet $\times$ hour interaction was found; 


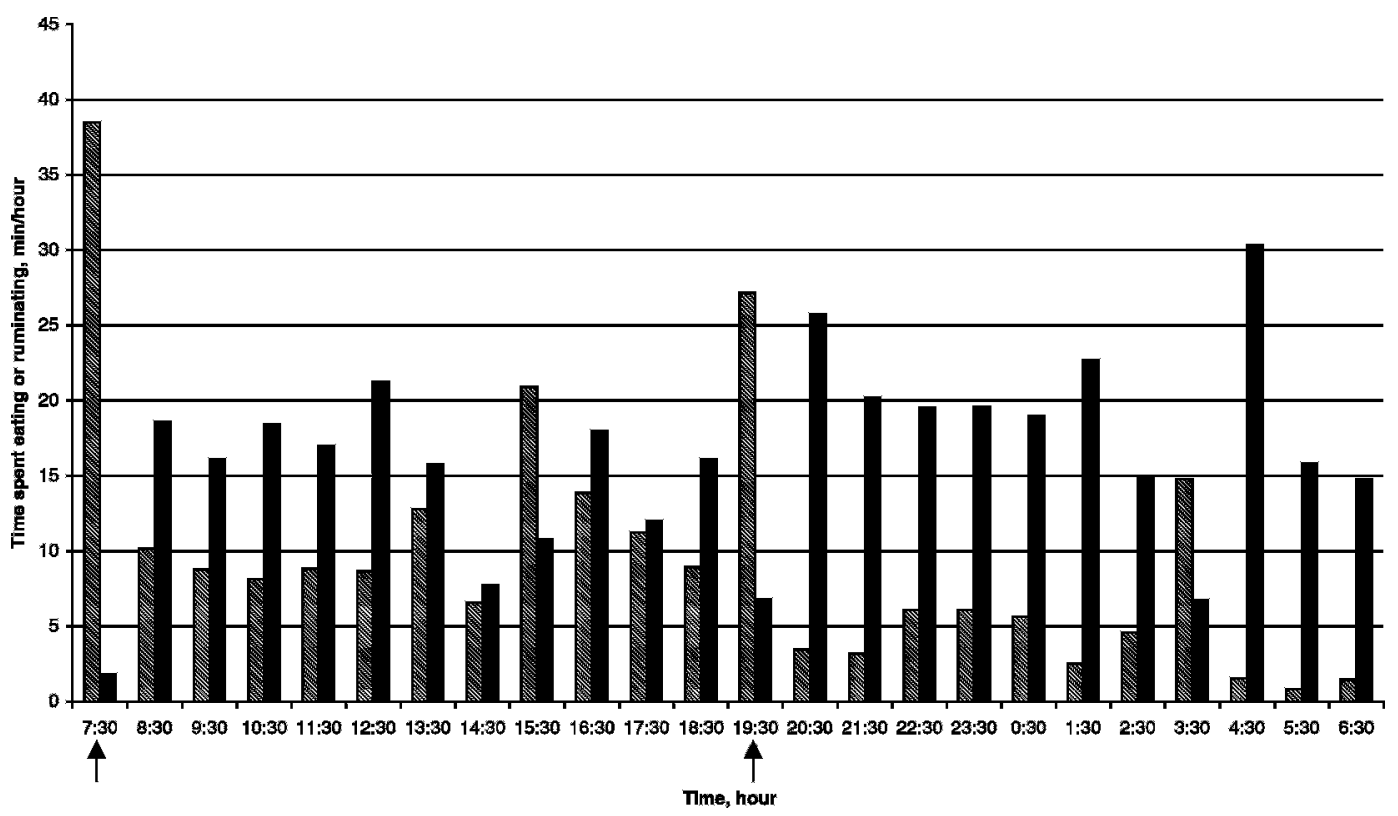

Figure 1. Daily eating and rumination activity averaged across diets. Arrows indicate time of feeding. Eating: stribed; rumination: solid.

therefore, only mean values are presented (Table 9). Total ruminal VFA concentration was not affected by dietary treatments nor was the concentration of acetate. Although many factors affect ruminal concentration of VFA, the similar VFA concentrations for all six diets, combined with the different DMI, indicate that diets differed in ruminal fermentability and/or in liquid passage rate. The concentration of propionate increased when forage particle size was decreased, which is in accordance with our previous observations (Krause et al., 2002b). Propionate concentration tended to increase $(P=0.09)$ when alfalfa silage was partially replaced by corn silage, probably caused by the increased amount of dietary starch. Butyrate concentration was unaffected by dietary treatments. The ratio of acetate to propionate tended to decrease $(P=0.10)$ when forage particle size was decreased and also tended to decrease $(P=0.09)$ when alfalfa silage was partially replaced by corn silage. Several of the diets fed in this study resulted in percentages of milk fat $<3$, but none of the acetate-

Table 9. Effects of dietary treatments on ruminal VFA concentrations.

\begin{tabular}{|c|c|c|c|c|c|c|c|c|c|c|c|c|}
\hline \multirow[b]{2}{*}{ Dependent variable } & \multicolumn{6}{|c|}{ Treatments $^{1}$} & \multirow[b]{2}{*}{$\mathrm{SED}^{2}$} & \multicolumn{5}{|c|}{ Statistical significance ( $P$-value) } \\
\hline & DCCA & DCCAC & DCFA & DCFAC & HMCCAC & HMCFAC & & $\mathrm{PS}^{3}$ & $\mathrm{RFC}^{4}$ & $\mathrm{~F}^{5}$ & $\begin{array}{l}\mathrm{PS} \times \\
\mathrm{RFC}\end{array}$ & $\begin{array}{l}\mathrm{PS} \times \\
\mathrm{F}\end{array}$ \\
\hline Total & 155.6 & 153.5 & 156.3 & 156.3 & 152.2 & 153.3 & 5.9 & 0.65 & 0.61 & 0.81 & 0.84 & 0.81 \\
\hline Acetate (A) & 94.5 & 90.1 & 91.9 & 88.8 & 89.2 & 86.8 & 4.3 & 0.40 & 0.64 & 0.22 & 0.86 & 0.84 \\
\hline Propionate (P) & 35.2 & 39.6 & 40.5 & 43.3 & 39.2 & 42.0 & 3.0 & 0.03 & 0.70 & 0.09 & 0.84 & 0.71 \\
\hline Butyrate & 18.7 & 16.9 & 17.3 & 16.8 & 16.9 & 16.4 & 1.4 & 0.42 & 0.82 & 0.25 & 0.85 & 0.52 \\
\hline Acetate & 60.8 & 58.8 & 58.8 & 56.9 & 58.7 & 56.7 & 1.3 & 0.01 & 0.87 & 0.03 & 0.99 & 0.98 \\
\hline Propionate & 22.6 & 25.7 & 25.7 & 27.6 & 25.8 & 27.4 & 1.9 & 0.05 & 0.97 & 0.07 & 0.91 & 0.66 \\
\hline Butyrate & 11.9 & 11.1 & 11.2 & 10.7 & 11.0 & 10.8 & 0.8 & 0.29 & 0.96 & 0.26 & 0.88 & 0.77 \\
\hline
\end{tabular}

\footnotetext{
${ }^{1}$ Treatments: DCCA = dry cracked shelled corn and coarse alfalfa silage, DCCAC = dry cracked shelled corn and coarse alfalfa/corn silage, DCFA = dry cracked shelled corn and fine alfalfa silage, DCFAC = dry cracked shelled corn and fine alfalfa/corn silage, HMCCAC = ground high-moisture shelled corn and coarse alfalfa/corn silage, HMCFAC = ground high-moisture shelled corn and fine alfalfa/corn silage.

${ }^{2} \mathrm{SED}=$ standard error of difference.

${ }^{3} \mathrm{PS}=$ forage particle size.

${ }^{4} \mathrm{RFC}=$ ruminally fermentable carbohydrate.

${ }^{5} \mathrm{~F}=$ forage source.
} 
Table 10. Effects of dietary treatments on ruminal $\mathrm{pH}$.

\begin{tabular}{|c|c|c|c|c|c|c|c|c|c|c|c|c|}
\hline \multirow[b]{2}{*}{ Dependent variable } & \multicolumn{6}{|c|}{ Treatments $^{1}$} & \multirow[b]{2}{*}{$\mathrm{SED}^{2}$} & \multicolumn{5}{|c|}{ Statistical significance $(P$-value $)$} \\
\hline & DCCAC & DCCAC & DCFA & DCFAC & HMCCAC & HMCFAC & & $\mathrm{PS}^{3}$ & $\mathrm{RFC}^{4}$ & $\mathrm{~F}^{5}$ & $\begin{array}{l}\mathrm{PS} \times \\
\mathrm{RFC}\end{array}$ & $\begin{array}{l}\mathrm{PS} \times \\
\mathrm{F}\end{array}$ \\
\hline Minimum daily $\mathrm{pH}$ & 5.53 & 5.26 & 5.45 & 5.40 & 5.19 & 5.13 & 0.10 & 0.96 & 0.02 & 0.02 & 0.16 & 0.12 \\
\hline $\begin{array}{l}\text { Time post feeding } \\
\text { for minimum } \mathrm{pH}, \mathrm{h}\end{array}$ & 5.9 & 7.0 & 5.2 & 5.6 & 6.2 & 5.9 & 0.6 & 0.03 & 0.61 & 0.10 & 0.19 & 0.37 \\
\hline Time below $\mathrm{pH} 5.8, \mathrm{~h} / \mathrm{d}$ & 7.8 & 13.4 & 10.1 & 9.5 & 12.7 & 15.9 & $\begin{array}{l}0.0 \\
1.8\end{array}$ & 0.61 & 0.04 & 0.05 & 0.006 & 0.02 \\
\hline
\end{tabular}

${ }^{1}$ Treatments: DCCA = dry cracked shelled corn and coarse alfalfa silage, DCCAC = dry cracked shelled corn and coarse alfalfa/corn silage, DCFA = dry cracked shelled corn and fine alfalfa silage, DCFAC $=$ dry cracked shelled corn and fine alfalfa/corn silage, HMCCAC $=$ ground high-moisture shelled corn and coarse alfalfa/corn silage, HMCFAC = ground high-moisture shelled corn and fine alfalfa/corn silage.

${ }^{2} \mathrm{SED}=$ standard error of difference.

${ }^{3} \mathrm{PS}=$ forage particle size.

${ }^{4} \mathrm{RFC}=$ ruminally fermentable carbohydrate.

${ }^{5} \mathrm{~F}=$ forage source.

to-propionate ratios were $<2$, which is the cut-off point that has been associated with milk fat depression (Erdman, 1988). When expressed on a molar percentage basis, decreasing forage particle size decreased percentage of acetate and increased percentage of propionate. A shift towards a lower proportion of acetate and a higher proportion of propionate was also observed by Le Liboux and Peyraud (1999), when chopped alfalfa was replaced by ground, pelleted alfalfa. Replacing part of the alfalfa silage with corn silage decreased the percentage of acetate and tended to increase $(P=0.07)$ the percentage of propionate. When Dhiman and Satter (1997) replaced one-third of the alfalfa silage with corn silage in a TMR containing 50\% forage (DM basis), they also found that the proportion of acetate tended to decrease, and the proportion of propionate tended to increase, resulting in a decreased acetate-to-propionate ratio. Molar percentage of butyrate was not affected by dietary treatments.

\section{Ruminal pH}

Ruminal $\mathrm{pH}$ was not different from day to day $(P=$ 0.47 ) and was not affected $(P=0.88)$ by feeding (morning vs. evening; data not shown). No interactions between day and dietary treatments or feeding and dietary treatments on $\mathrm{pH}$ were observed. Diurnal fluctuations in ruminal $\mathrm{pH}$ for the dietary treatments are shown in Figure 2. All six diets resulted in similar diurnal patterns. Ruminal $\mathrm{pH}$ declined immediately after the morning feeding and did not start to increase again until after the evening feeding. This pattern is somewhat surprising, considering that cows were fed twice daily. In a previous study, where cows were fed twice daily, $\mathrm{pH}$ showed a biphasic pattern related to the two feedings (Krause et al, 2002b). However, in this study, equal amounts of feed were allocated at each of the feeding. Also, in the previous study, daily DMI was 2 $\mathrm{kg}$ higher. This difference in postprandial $\mathrm{pH}$ pattern for the morning vs. the evening feeding appeared as an interaction between feeding and hours after feeding ( $P$ $<0.001$; data not shown). The pattern associated with the morning feeding was characterized by a higher initial $\mathrm{pH}$ than that for the evening feeding (5.99 vs. 5.63) but a lower $\mathrm{pH}$ at the time of the next feeding than for the evening feeding (5.69 vs. 6.09 ). Whereas $\mathrm{pH}$ showed a steady decline between the morning and evening feedings, the opposite was the case between the evening and morning feedings (Figure 3). This difference in ruminal $\mathrm{pH}$ pattern between the two feedings was probably caused by the diurnal eating and rumination pattern. Most of the feed was allocated at the morning feeding $(\sim 65 \%)$ and the majority of the eating activity (67\%) took place during the $12 \mathrm{~h}$ after the morning feeding. The greater time spent eating during the day probably translated into a higher DMI during the day compared to during the night, resulting in a lower $\mathrm{pH}$ at the time of the evening feeding than at the time of the morning feeding.

Mean ruminal $\mathrm{pH}$ was $<6$ for all of the dietary treatments (Table 10). Mean ruminal $\mathrm{pH}$ was not affected by forage particle size, which was unexpected, based on results from a previous study (Krause et al., 2002b). However, in the previous study, the difference in forage particle size between coarse and fine ( $13.6 \mathrm{vs} .3 .7 \mathrm{~mm}$, respectively) was greater than in the present study. Mean ruminal $\mathrm{pH}$ decreased from 5.82 to 5.67 when HMC replaced DC in the diet. When Knowlton et al. (1996) increased level of ruminally fermented carbohydrate by replacing cracked dry corn with ground dry corn, they found no effect on mean ruminal $\mathrm{pH}$ but did report an increase in the range of ruminal $\mathrm{pH}$ within 


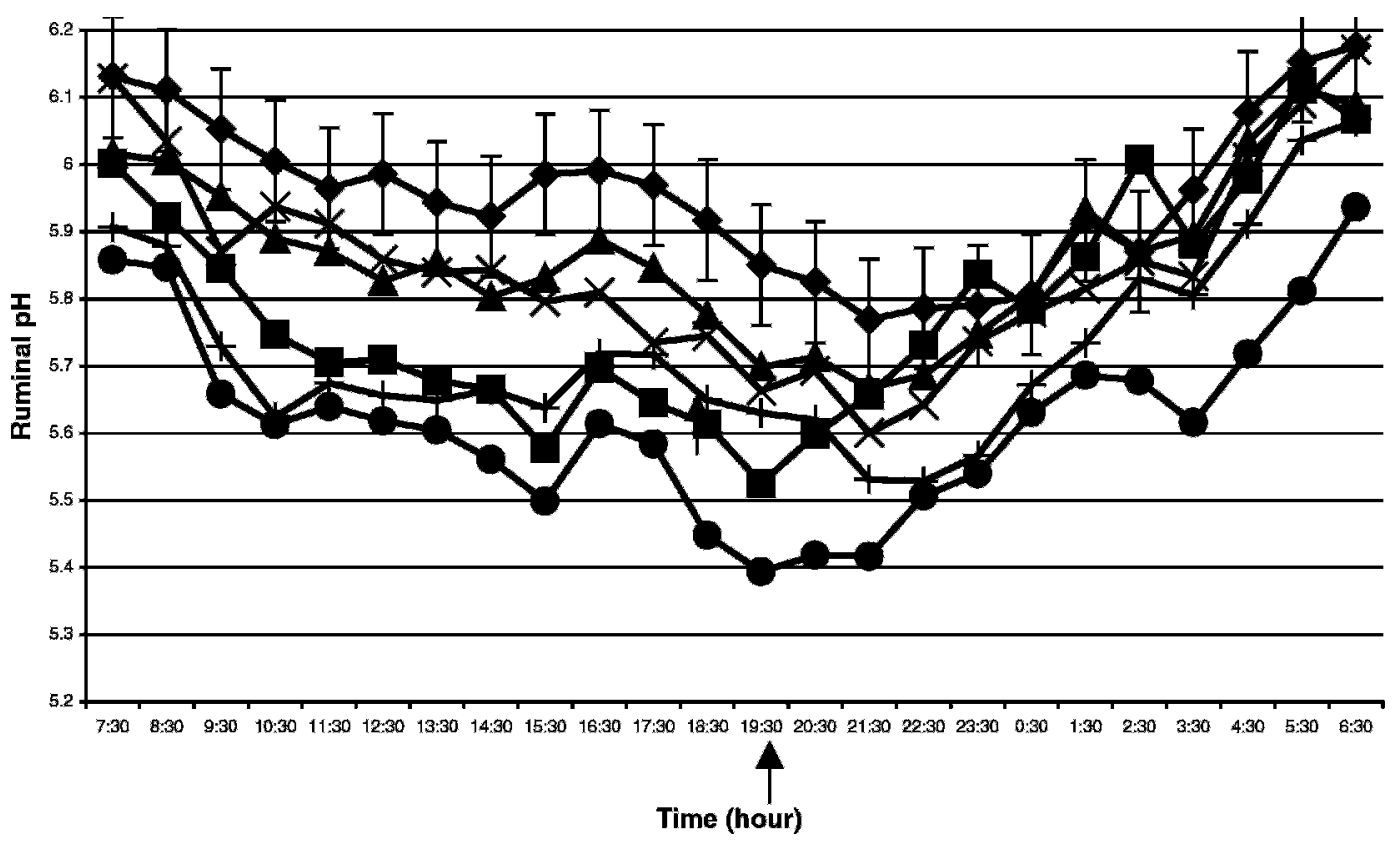

Figure 2. Diurnal fluctuations in ruminal $\mathrm{pH}$ for diets differing in forage particle size, level of ruminally fermentable carbohydrate and forage source. Arrows indicate time of feeding. DCCA: $\bullet$; DCCAC: $\mathbf{\square}$; DCFA: $\mathbf{\Delta}$; DCFAC: $\times$; HMCAC: +; HMCFAC: $\bullet$. DCCA = dry cracked shelled corn and coarse alfalfa silage, DCCAC = dry cracked shelled corn and coarse alfalfa/corn silage, DCFA = dry cracked shelled corn and fine alfalfa silage, DCFAC = dry cracked shelled corn and fine alfalfa/corn silage, HMCCAC = ground high-moisture shelled corn and coarse alfalfa/corn silage, HMCFAC = ground high-moisture shelled corn and fine alfalfa/corn silage.

a day. Our results are in agreement with the results by Yang et al. (2001), who reported that ruminal $\mathrm{pH}$ was not correlated with effective NDF intake but tended to be correlated with digestion of starch in the rumen. No effect of forage source on mean ruminal $\mathrm{pH}$ was found ( $P=0.11$ ), which is in agreement with the results reported by Dhiman and Satter (1997), who replaced up to two-thirds of the alfalfa silage with corn silage and measured ruminal $\mathrm{pH} 15$ times within a 24-h period. Forage source was expected to affect ruminal $\mathrm{pH}$, as

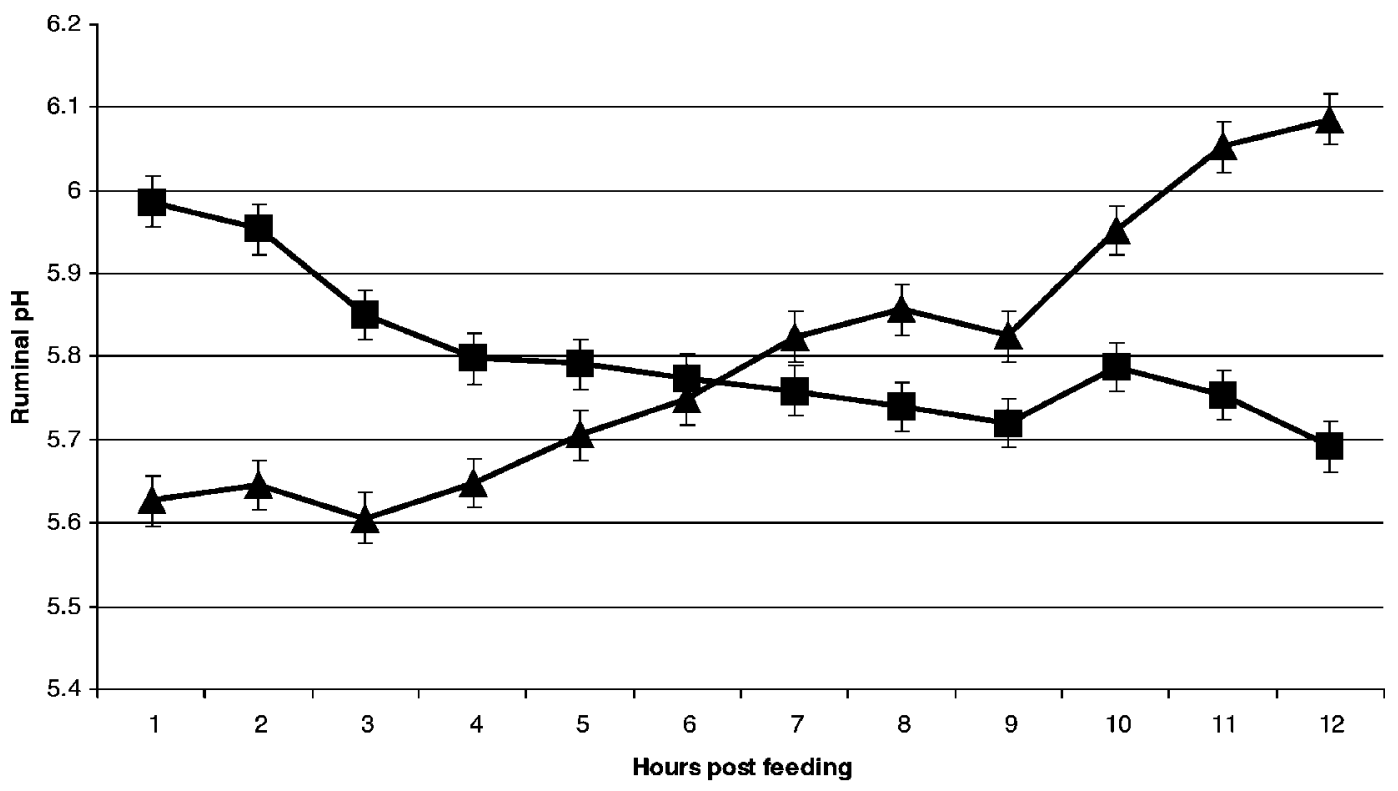

Figure 3. Effect of feeding (morning vs. evening) on ruminal pH pattern. Morning feeding: $\mathbf{\square}$; Evening feeding: $\boldsymbol{\Delta}$. 
replacing alfalfa silage with corn silage increased level of dietary starch and also because of the buffering capacity of alfalfa silage compared to corn silage (Van Soest et al., 1991). Minimum daily $\mathrm{pH}$ decreased when level of RFC was increased and also decreased when corn silage partially replaced alfalfa silage. Ruminal $\mathrm{pH}$ reached its lowest point sooner after feeding when forage particle size was reduced. When a mix of alfalfa and corn silage was fed, time of nadir post feeding occurred later than if alfalfa silage was the only forage. The time of post feeding nadir differed for the two feedings (morning vs. evening; $P<0.001$ ). Post feeding nadir occurred $7.2 \mathrm{~h}$ after the morning feeding but only 4.8 $\mathrm{h}$ after the evening feeding (data not shown). Hours per day at which $\mathrm{pH}$ was below 5.8 increased from 4.4 to $6.4 \mathrm{~h}$ when level of RFC was increased and when corn silage partially replaced alfalfa silage ( 2.6 vs. $4.4 \mathrm{~h}$ ). When forage particle size was decreased, hours spent $<\mathrm{pH} 5.8 / \mathrm{d}$ increased for diets containing HMC but decreased for the similar diets containing DC, as evidenced by a significant interaction between level of RFC and forage particle size. An interaction was also found between forage particle size and source of forage; when forage particle size was reduced for diets containing DC and only alfalfa silage as forage, hours $<\mathrm{pH} 5.8 / \mathrm{d}$ increased, whereas it actually decreased for diets containing DC and both alfalfa silage and corn silage. Area below $\mathrm{pH} 5.8(\mathrm{~h} \times \mathrm{pH}$ units/d) increased from 11.4 to $14.3 \mathrm{~h} \times \mathrm{pH}$ when level of RFC was increased, and increased from 8.9 to $11.4 \mathrm{~h} \times \mathrm{pH}$ when corn silage partially replaced alfalfa silage. As for hours spent $<\mathrm{pH}$ $5.8 / \mathrm{d}$ an interaction was found between forage particle size and level of RFC; for diets containing DC and mixed forages, area $<\mathrm{pH} 5.8$ was decreased when forage particle size was decreased, whereas for diets containing $\mathrm{HMC}$, area $<\mathrm{pH} 5.8 / \mathrm{d}$ was increased when forage particle size was decreased. Why reducing forage particle size in diets based on DC and mixed forages resulted in a numerical increase in mean $\mathrm{pH}$ and a decrease in hours and $<\mathrm{pH} 5.8$ is unclear. Intake of DM and starch was higher for the DCCAC diet compared to DCFAC (23.5 vs. $22.0 \mathrm{~kg}$ and 8.93 vs. $8.24 \mathrm{~kg}$, respectively) but not to a degree that would explain the difference in ruminal $\mathrm{pH}$. Decreasing forage particle size in these diets also decreased time spent chewing from 11.8 to $9.3 \mathrm{~h} / \mathrm{d}$, which would decrease the amount of buffered saliva secreted.

\section{CONCLUSIONS}

Decreasing forage particle size in diets based on either alfalfa silage or a mix of alfalfa silage and corn silage decreased intake of DM and OM. Intake of DM and $\mathrm{OM}$ decreased when level of RFC was increased by replacing DC with HMC in diets containing a mix of alfalfa and corn silage. As demonstrated in this study, the effect of reducing the level of physically effective fiber on percentage of milk fat and yield depends on the source of forage. Increasing the proportion of the starch digested in the rumen further decreases percentage of milk fat and yield in high starch diets. Total tract digestibilities of DM, OM, and starch were increased when level of RFC was increased by replacing DC with HMC.

Decreasing forage particle size decreased eating and rumination time. Partially replacing alfalfa silage with corn silage increased rumination time, also when expressed per kilogram of DMI and per kilogram of NDF intake, even though particle sizes of the forages were similar. Replacing DC with HMC in mixed forage diets further increased time spent ruminating per kilogram of DMI and per kilogram of NDF intake, indicating that the physically effective factor of forages depends on factors other than particle size.

The response variable mean ruminal $\mathrm{pH}$ was only affected by level of ruminally fermentable carbohydrates, but other $\mathrm{pH}$ variables such as minimum $\mathrm{pH}$, hours spent $<\mathrm{pH} 5.8$, and area $<\mathrm{pH} 5.8$ were affected by source of forage and level of RFC. Also, the effect of forage particle size on these variables depended on forage source and level of RFC. These results emphasize the importance of considering not only mean $\mathrm{pH}$, but also diurnal variations when assessing the effect of diets on rumen environment.

Effects of interactions between level of physically effective fiber, forage source, and level of RFC were found on both production variables and ruminal $\mathrm{pH}$ variables in this study. This indicates that these effects are not always additive, complicating the inclusion of these effects in dairy ration formulation and evaluation programs.

\section{ACKNOWLEDGMENTS}

The authors thank Jerry Guenther, Robert Elderbrook and the rest of the staff at the Dairy Cattle Research Center for the care and feeding of the cows.

\section{REFERENCES}

Allen, M. S. 1997. Relationship between fermentation acid production in the rumen and the requirement for physically effective fiber. J. Dairy Sci. 80:1447-1462.

American National Standards Institute. 1988. Method of determining and expressing particle size of chopped forage materials by screening. ASAE S424, ASAE, St. Joseph, MI.

American National Standards Institute. 1995. Method of determining and expressing fineness of feed material by sieving. ASAE Standards 1995 p. 461, ASAE, St. Joseph, MI.

Association of Official Analytical Chemists. 1990. Official Methods of Analysis. Vol. I. 15th ed. AOAC, Arlington, VA. 
Bailey, C. B., and C. C. Balch. 1961. Saliva secretion and its relation to feeding in cattle. 2. The composition and rate of secretion in the cow during rest. Br. J. Nutr. 15:371-382.

Bal, M. A., R. D. Shaver, A. G. Jirovec, K. J. Shinners, and J. G. Coors. 2000. Crop processing and chop length of corn silage: Effects on intake, digestion, and milk production by dairy cows. J. Dairy Sci. 83:1264-1273.

Beauchemin, K. A. 1991. Effects of dietary neutral detergent fiber concentration and alfalfa hay quality on chewing, rumen function, and milk production of dairy cows. J. Dairy Sci. 74:3140-3151.

Calsamiglia, S., A. Ferret, and M. Devant. 2002. Effects of $\mathrm{pH}$ and $\mathrm{pH}$ fluctuations on microbial fermentation and nutrient flow from a dual-flow continuous culture system. J. Dairy Sci. 85:574-579.

Chen, X. B., and M. J. Gomes. 1992. Estimation of microbial protein supply to sheep and cattle based on urinary excretion of purine derivatives - an overview of the tehcnical details. International Feed Resources Unit, Rowett Research Institute, Bucksburn, Aberdeen, AB2 9SB, UK. Occasional Publication.

Clark, P. W., and L. E. Armentano. 1998. Effect of particle size on the effectiveness of fiber in alfalfa silage. J. Dairy Sci. 81(Suppl. 1):290 (Abstr.).

Combs, D. K., and L. D. Satter. 1992. Determination of markers in digesta and feces by direct-current plasma emission-spectroscopy. J. Dairy Sci. 75:2176-2183.

Dhiman. T. R., and L. D. Satter. 1997. Yield response of dairy cows fed different proportions of alfalfa silage and corn silage. J. Dairy Sci. 80:2069-2082.

Erdman, R. A. 1988. Dietary buffering requirements of the lactating dairy cow: A review. J. Dairy Sci. 71:3246-3266.

Fischer, J. M., J. G. Buchanan-Smith, C. Campbell, D. G. Grieve, and O.B. Allen. 1994. Effects of forage particle size and long hay for cows fed total mixed rations based on alfalfa and corn. J. Dairy Sci. 77:217-229.

Goering, H. K., and P. J. Van Soest. 1970. Forage Fiber Analyses. (Apparatus, Reagents, Procedures, and Some Applications). Agric. Handbook No. 379. ARS-USDA, Washington, DC.

Grant, R. J., V. F. Colenbrander, and D. R. Mertens. 1990a. Milk fat depression in dairy cows: role of particle size of alfalfa hay. J. Dairy Sci. 73:1823-1833.

Grant, R. J., V. F. Colenbrander, and D. R. Mertens. 1990b. Milk fat depression in dairy cows: role of silage particle size. J. Dairy Sci. 73:1834-1842.

Hartnell, G. F., and L. D. Satter. 1979. Determination of rumen fill, retention time, and ruminal turnover rates of ingesta at different stages of lactation in dairy cows. J. Anim. Sci. 48:381-392.

Knowlton, K. F., M. S. Allen, and P. S. Erickson. 1996. Lasalocid and particle size of corn grain for dairy cows in early lactation. 2. Effect on ruminal measurements and feeding behavior. J. Dairy Sci. 79:565-574.

Kononoff, P. J., A. J. Heinrichs, D. R. Buckmaster, and K. J. Harvatine. 1999. A characterization of effective fiber: the effective fiber index system. J. Dairy Sci. 82(Suppl. 1):85 (Abstr.).

Krause, K. M., D. K. Combs, and K. A. Beauchemin. 2002a. Effects of forage particle size and grain fermentability in midlactation cows. I. Milk production and diet digestibility. J. Dairy Sci. 85:1936-1946.

Krause, K. M., D. K. Combs, and K. A. Beauchemin. 2002b. Effects of forage particle size and grain fermentability in midlactation cows. II. Ruminal $\mathrm{pH}$ and chewing activity. J. Dairy Sci. 85:1947-1957.
Le Liboux, S., and J. L. Peyraud. 1999. Effect of forage particle size and feeding frequency on fermentation patterns and sites and extent of digestion in dairy cows fed mixed diets. Anim. Feed Sci. Tech. 76:297-319.

Mertens, D. R. 1997. Creating a system for meeting the fiber requirements of dairy cows. J. Dairy Sci. 80:1463-1481.

Mertens, D. R. 1999. Variation in NDF results with modifications of the filter bag method. National Forage Testing Association, Technical sessions, papers, and committee reports to the board and membership, June 1999, Topeka, Kansas.

Mooney, C. S., and M. S. Allen. 1997. Physical effectiveness of the neutral detergent fiber of whole linted cottonseed relative to that of alfalfa silage at two lengths of cut. J. Dairy Sci. 80:2052-2061.

National Research Council. 2001. Nutrient Requirements of Dairy Cattle. 7th rev. ed. Natl. Acad. Press, Washington, DC.

Nocek, J. E., and S. Tamminga. 1991. Site of digestion of starch in the gastrointestinal tract of dairy cows and its effect on milk yield and composition. J. Dairy Sci. 74:3598-3629.

Oba, M., and M. S. Allen. 2000. Effects of conservation method of corn grain and dietary starch content on DMI and productivity of lactating dairy cows. J. Dairy Sci. 83(Suppl. 1):1043 (Abstr.).

$\mathrm{SAS}^{\circledR}$ User's Guide: Statistics, Version 7 Edition. 1998. SAS Inst., Inc., Cary, NC.

Shaver, R. D., A. J. Nytes, L. D. Satter, and N. A. Jorgensen. 1986. Influence of amount of feed and forage physical form on digestion and passage of prebloom alfalfa hay in dairy cows. J. Dairy Sci. 69:1545-1559.

Strobel, H. J., and J. B. Russell. 1986. Effect of $\mathrm{pH}$ and energy spilling on bacterial protein synthesis by carbohydrate-limited cultures of mixed rumen bacteria. J. Dairy Sci. 69:2941-2947.

Tyrrell, H. F., and J. T. Reid. 1965. Prediction of the energy value of cow's milk. J. Dairy Sci. 48:1215-1223.

Valadares, R. F. D., G. A. Broderick, S. C. Valadares Filho, and M. K. Clayton. 1999. Effect of replacing alfalfa silage with highmoisture corn on ruminal protein synthesis estimated from excretion of total purine derivatives. J. Dairy Sci. 82:2686-2696.

Van Soest, J. P., J. B. Robertson, and B. A. Lewis. 1991. Methods for dietary fiber, neutral detergent fiber, and nonstarch polysaccharides in relation to animal nutrition. J. Dairy Sci. 74:35833597.

Varel, V. H., and K. K. Kreikemeier. 1995. Technical note: Comparison of in vitro and in situ digestibility methods. J. Anim. Sci. 73:578-582.

Wangsness, P. J., L. E. Chase, A. D. Peterson, T. G. Hartsock, D. J. Kellmel, and B. R. Baumgardt. 1976. System for monitoring feeding behavior of sheep. J. Anim. Sci. 42:1544-1549.

Woodford, J. A., N. A. Jorgensen, and G. P. Barrington. 1986. Impact of dietary fiber and physical form on performance of lactating dairy cows. J. Dairy Sci. 71:674-686.

Woodford, S. T., and M. R. Murphy. 1988. Effect of forage physical form on chewing activity, dry matter intake, and rumen function of dairy cows in early lactation. J. Dairy Sci. 71:674-686.

Yang, W. Z., K. A. Beauchemin, and L.M. Rode. 2001. Effects of grain processing, forage-to-concentrate ratio, and forage particle size on rumen $\mathrm{pH}$ and digestion by dairy cows. J. Dairy Sci. 84:2203-2216.

Ying, Y., M. S. Allen, M. J. VandeHaar, and N. K. Ames. 1998. Effects of fineness of grinding and conservation method of corn grain on ruminal and whole tract digestibility and ruminal microbial protein production of Holstein cows in early lactation. J. Dairy Sci. 81(Suppl. 1):1330 (Abstr.). 